\title{
Microbial Cell Factories for Green Production of Vitamins
}

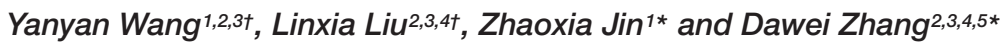 \\ ${ }^{1}$ School of Biological Engineering, Dalian Polytechnic University, Dalian, China, ${ }^{2}$ Key Laboratory of Systems Microbial \\ Biotechnology, Chinese Academy of Sciences, Tianjin, China, ${ }^{3}$ Tianjin Institute of Industrial Biotechnology, Chinese Academy \\ of Sciences, Tianjin, China, ${ }^{4}$ National Technology Innovation Center of Synthetic Biology, Tianjin, China, ${ }^{5}$ University \\ of Chinese Academy of Sciences, Beijing, China
}

OPEN ACCESS

Edited by:

Dipesh Dhakal,

University of Florida, United States

Reviewed by:

Ana Margarida Goncalves

Carvalho Dias,

New University of Lisbon, Portugal

Angel León-Buitimea,

Universidad Autonoma de Nuevo

Leon, Mexico

*Correspondence:

Zhaoxia Jin

jinzx2018@163.com

Dawei Zhang

zhang_dw@tib.cas.cn

tThese authors have contributed equally to this work

Specialty section:

This article was submitted to Synthetic Biology,

a section of the journal

Frontiers in Bioengineering and

Biotechnology

Received: 31 January 2021 Accepted: 12 May 2021

Published: 17 June 2021

Citation:

Wang Y, Liu L, Jin Z and Zhang D (2021) Microbial Cell Factories

for Green Production of Vitamins.

Front. Bioeng. Biotechnol. 9:661562.

doi: 10.3389/fbioe.2021.661562
Vitamins are a group of essential nutrients that are necessary to maintain normal metabolic activities and optimal health. There are wide applications of different vitamins in food, cosmetics, feed, medicine, and other areas. The increase in the global demand for vitamins has inspired great interest in novel production strategies. Chemical synthesis methods often require high temperatures or pressurized reactors and use nonrenewable chemicals or toxic solvents that cause product safety concerns, pollution, and hazardous waste. Microbial cell factories for the production of vitamins are green and sustainable from both environmental and economic standpoints. In this review, we summarized the vitamins which can potentially be produced using microbial cell factories or are already being produced in commercial fermentation processes. They include water-soluble vitamins (vitamin B complex and vitamin C) as well as fat-soluble vitamins (vitamin A/D/E and vitamin K). Furthermore, metabolic engineering is discussed to provide a reference for the construction of microbial cell factories. We also highlight the current state and problems encountered in the fermentative production of vitamins.

Keywords: vitamins, metabolic engineering, microbial cell factory, chemical synthesis, biosynthesis

\section{INTRODUCTION}

Vitamins are essential for proper growth and health of animals, that cannot produce vitamins by themselves or that synthesize insufficient amount to cover all their needs (Capone and Sentongo, 2019; Suter, 2020). The methods of producing vitamins are based either on chemical synthesis or fermentative production (Yuan et al., 2020).

There are at least 30 kinds of different compounds considered "vitamins," more than 20 vitamins of which are known to be necessary for biological health. Vitamins are either water-soluble or fatsoluble. As the name suggests, a water-soluble vitamin dissolves in water easily and insoluble in organic solvents. After absorption, the body stores very little of such proteins, and most are excreted with urine (Berdanier and Adkins, 2019). Fat-soluble vitamins are dissolved in fats but not in water, and which are stored in the liver or fatty tissues for future use. While vitamins are essential nutrients for all living things, many plants and microorganisms can synthesize them naturally by themselves. By contrast, humans and other animals need to acquire sufficient vitamins with their diet or through supplements to maintain optimal health (Blake and Konings, 2019).

Traditionally, vitamin production strains have been improved through mutagenesis and metabolic engineering, which can be conducted either through chemical or biological means 
(Vandamme and Revuelta, 2016b). The main chemical strategies include chemical mutagenesis, application of $\mathrm{N}^{+}$ion beam, ultraviolet radiation or laser mutagenesis. The biological methods mainly include the construction and mutagenesis of the starting strain, genetic modification, synthetic biotechnology, optimization of media and culture conditions, construction of biofilm reactors, etc. (Nie et al., 2013; Song et al., 2014). A series of biotechnological methods are used to transform the metabolic network of cells to construct a programmable "chassis" and "programmable" whole, which can be used to develop an effective assembly strategy, test the adaptability of external components and modules after loading, forming a fine-tuned and customized biological application system. To drive the iterative evolution of other industrial strains, and effectively promote the transformation and renewal of high vitamin producing strains. Chemical methods are usually expensive, environmentunfriendly, waste-prone, and the costly waste disposal. However, the microbial fermentation method has attracted much attention due to low cost, low energy consumption and easy waste recycling. At present, the fermentation method has been recognized by researchers, and it is more environment-friendly and safe than chemical methods. As the fermentation technology matures, this approach is increasingly being used in industry to increase the production of different vitamins. For example, fermentation processes for the production of vitamin $B_{2}\left(V_{2}\right)$, vitamin $\mathrm{B}_{12}\left(\mathrm{VB}_{12}\right)$, vitamin $\mathrm{C}$, and vitamin $\mathrm{K} 2$ have all been industrialized successfully.

Acevedo-Rocha et al. (2019) reviewed the fermentation of $B$ vitamins from the aspect of sustainability. In this review, we mainly discuss vitamins that can be produced by green fermentation processes. It covers water-soluble vitamins, including vitamin $\mathrm{C}$ and vitamin $\mathrm{B}$ complex (thiamine, riboflavin, niacin, pantothenic acid, pyridoxine, biotin, folate, and cobalamin) as well as the fat-soluble vitamin $\mathrm{E}$ and vitamin $\mathrm{K}$. Here, we discussed the producing microorganisms, advanced biological methods and metabolic bottlenecks of different vitamins.

\section{WATER-SOLUBLE VITAMINS}

\section{B Vitamins}

The global demand for B vitamins is growing due to wide applications in food, pharmaceuticals, feed, and other fields. Although most vitamins are manufactured by chemical synthesis, successful industrial bioprocesses have been established for the production of $\mathrm{VB}_{2}$ and $\mathrm{VB}_{12}$. The underlying extraordinary achievement in metabolic engineering is discussed in this article.

\section{Vitamin $\mathrm{B}_{\mathbf{1}}$}

Vitamin $B_{1}$, which is also known as thiamine, was the first $B$ vitamin to be identified. Thiamine pyrophosphate (TPP), the active form of thiamine, can inhibit the activity of cholinesterase, reduce skin inflammation, prevent seborrheic dermatitis, or eczema, and improve skin health. Thiamine biosynthesis results from the coupling of the pyrimidine and the thiazole moieties to form thiamine phosphate (Dorrestein et al., 2004;
Jurgenson et al., 2009; Cea et al., 2020). Escherichia coli, Salmonella typhimurium, and Bacillus subtilis are the most thoroughly studied thiamine production organisms (Begley et al., 1999).

In chassis cell S. typhimurium, the thiamine pyrimidine moiety can be produced through de novo purine biosynthesis or independently of the purF gene through the alternative pyrimidine biosynthesis (APB) pathway (Downs and Roth, 1991; Downs, 1992). According to the phenotypic characteristics of the abpA mutant, follow-up studies concluded that the functional APB pathway is essential for thiamine synthesis when S. typhimurium grows in the presence of exogenous purines (Downs and Petersen, 1994). Research has shown that overexpression of thiA, nmtA, and thiP in Aspergillus oryzae can increase the vitamin $B_{1}$ yield fourfold compared to the wildtype (Tokui et al., 2011). Based on the riboswitch mechanism, mutations in the genes of thiamine pyrophosphate kinase activity (thiN) and thiamine-related transport proteins (YkoD and YuaJ) were introduced in B. subtilis TH95. It was recently reported that thiamine biosynthesis is strictly regulated by TPP riboswitches in bacteria/eukaryotes and transcriptional repressors in archaea (Hwang et al., 2017). E. coli has emerged as the preferred cell factory for TPP production after a riboswitch-based biosensors enabled the discovery of thiamine transporters, combined with overexpression of the native thiFSGHCE and thiD genes, which are closely related to Fe-S metabolism (Figure 1A and Table 1; Cardinale et al., 2017).

However, thiC/thiH in the thiamine biosynthetic pathway is involved in $\mathrm{Fe}-\mathrm{S}$ metabolism and is inhibited by $S$-adenosylmethionine (SAM) metabolites, and the catalytic activity of ThiC enzyme (Figure 2$)$ is very low $\left(k_{\text {cat }}=0.002 \mathrm{~s}^{-1}\right)$ which is one of the main metabolic bottlenecks (Palmer and Downs, 2013). In addition, the cost of chemical production of thiamine is very low, and the production of engineered strains needs to be increased to be expected to be industrialized.

\section{Vitamin $\mathrm{B}_{\mathbf{2}}$}

Riboflavin is an important precursor of flavin mononucleotide (FMN) and flavin adenine dinucleotide (FAD) (Balasubramaniam et al., 2019; Andreieva et al., 2020). Riboflavin insufficiency manifests as persistent anemia (Shi et al., 2014). The biosynthesis of riboflavin begins with guanosine triphosphate and ribose-5-phosphate, followed by six enzymatic steps (Fischer and Bacher, 2005). Burgess et al. (2004) found that overexpression of the ribABCGH genes can increase riboflavin production. Later, it was found that there were both nucleotide substitutions and deletions in the regulatory region of the rib operon. By deregulating the rib operon and purine pathway of $B$. subtilis, riboflavin production was greatly improved. The specific genetic engineering steps included overexpression of the ribA gene and deletion of the purR gene, after which maximum output of riboflavin reached more than $826.52 \mathrm{mg} / \mathrm{L}$ (Figure 1B; Shi et al., 2014). In Candida famata overexpression of sef1 and imh3 was combined with classic mutagenesis methods to construct the high riboflavin-producing strain AF-4. As a result, $1026 \pm 50 \mathrm{mg} / \mathrm{L}$ of riboflavin can be produced during a fed-batch cultivation in a lab-scale fermenter. This research has 


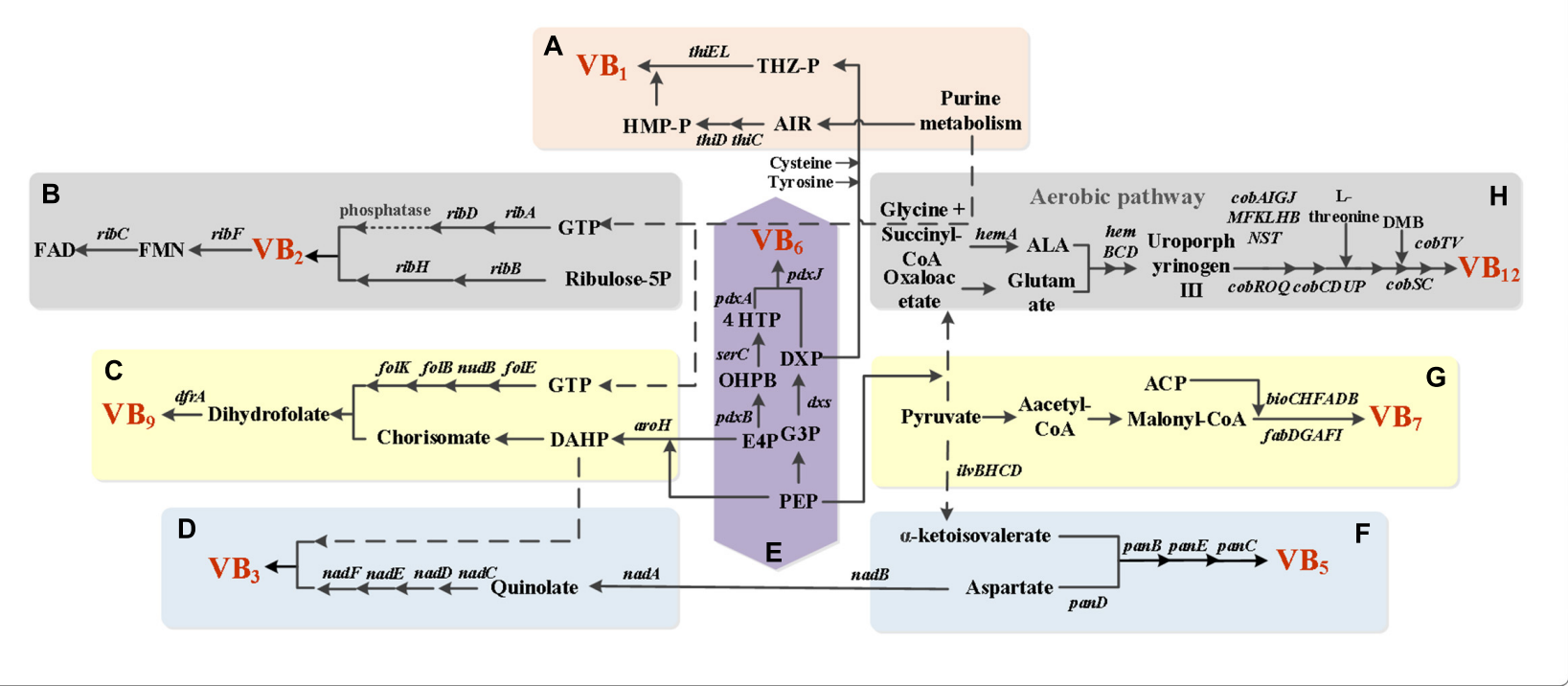

FIGURE 1 | Metabolic network pathway of B vitamins. (A) Biosynthesis pathway of thiamine in E. coli. ThiC/ThiD, phosphomethylpyrimidine synthase; ThiE, thiamine-phosphate pyrophosphorylase; ThiL, thiamine-monophosphate kinase. (B) Biosynthesis pathway of riboflavin in B. subtilis. RibA, GTP cyclohydrolase II; RibB, 3,4-dihydroxy 2-butanone 4-phosphate synthase; RibD, diaminohydroxyphosphoribosylaminopyrimidine deaminase; RibH, 6,7-dimethyl-8-ribityllumazine synthase. RibF, FMN adenylyltransferase; RibC, riboflavin synthase. (C) Vitamin $B_{9}$ biosynthesis pathway in B. subtilis. AroH, chorismate mutase; FolE, GTP cyclohydrolase IA; NudB, dihydroneopterin triphosphate diphosphatase; FolB, 7,8-dihydroneopterin aldolase/epimerase/oxygenase; FolK,

2-amino-4-hydroxy-6-hydroxymethyldihydropteridine diphosphokinase; DfrB, dihydrofolate reductase. (D) Vitamin $B_{3}$ biosynthesis pathway in E. coli. NadB, L-aspartate oxidase; NadA, quinolinate synthase; NadC, nicotinate-nucleotide pyrophosphorylase; NadD, nicotinate-nucleotide adenylyltransferase; NadE/NadF, NAD + synthase. (E) De novo biosynthesis pathway of vitamin $B_{6}$. PdxB, erythronate-4-phosphate dehydrogenase; SerC, phosphoserine aminotransferase; PdxA, 4-hydroxythreonine-4-phosphate dehydrogenase; PdxJ, pyridoxine 5-phosphate synthase; Dxs, 1-deoxy-D-xylulose-5-phosphate synthase. (F) Pathway for de novo synthesis of vitamin $\mathrm{B}_{5}$. il $\mathrm{V} B H C D$, increased the transcription levels of the ilv genes; panDBEC, pantothenate biosynthetic genes. (G) Biosynthesis pathway of Vitamin $\mathrm{B}_{7}$ in E. coli. BioC, malonyl-CoA O-methyltransferase; BioH, pimeloyl-[acyl-carrier protein] methyl ester esterase; BioF, 8-amino-7-oxononanoate synthase; BioA, 8-amino-7-oxononanoate aminotransferase; BioD, dethiobiotin synthetase; BioB, biotin synthase; FabD, S-malonyltransferase; FabG, 3-oxoacyl-(acyl-carrier protein) reductase; FabA, 3-hydroxyacyl-(acyl-carrier protein) dehydratase; FabF, 3-oxoacyl-(acyl-carrier-protein) synthase II; Fabl, enoyl-(acyl-carrier protein) reductase I. (H) The aerobic pathway in the synthesis pathway of cobalamin. HemA, glutamyl-tRNA reductase; ALA, $\delta$-aminolevulinate; HemB, porphobilinogen synthase; HemC, hydroxymethylbilane synthase; HemD, uroporphyrinogen-III synthase; CobA, uroporphyrin-III C-methyltransferase; Cobl, precorrin-2 C(20)-methyltransferase; CobG, precorrin-3B synthase; CobJ, precorrin-3B C17-methyltransferase; CobF, precorrin-6A synthase; CobK, precorrin-6A/cobalt-precorrin-6A reductase; CobL, precorrin-6B methyltransferase; CobH, precorrin-8X/cobalt-precorrin-8 methylmutase; CobB, cobyrinic acid a,c-diamide synthase; cobNST, hydrogenobyrinic-acid-a,c-diamide:cobalt cobalt-ligase; CobR, cob(Il)yrinic acid a,c-diamide reductase; CobO/CobP, corrinoid adenosyltransferase; CobQ, adenosylcobyric acid synthase; CobS/CobV, adenosylcobinamide-GDP ribazoletransferase; CobC, cobalamin biosynthesis protein; CobD, adenosylcobinamide-phosphate synthase; CobU/CobT, nicotinate-nucleotide-dimethylbenzimidazole phosphoribosyltransferase.

made a great contribution to industrial production of riboflavin (Dmytruk et al., 2011, 2014). The two most important industrial producers are Ashbya gossypii and B. subtilis.

In $A$. gossypii, malate synthase in the glyoxylate cycle is essential for riboflavin production. Deletion of the malate synthase gene (ACR268C) decreased riboflavin production 10-fold compared to the wild-type strain. Conversely, overexpression of the $A C R 286 C$ gene significantly increased the yield of riboflavin by $70 \%$. These results demonstrated that malate synthase is a new target for improving the production of riboflavin (Sugimoto et al., 2009). Abbas and Sibirny (2011) introduced the $i c l$ gene, overexpressed the $g l y 1$, prs2,4, and prs3 genes, as well as knocking out the vma4, shm2, and bas 1 genes, resulting in riboflavin production of more than $20 \mathrm{~g} / \mathrm{L}$.

In B. subtilis, Schwechheimer et al. (2016) overexpressed riboflavin biosynthesis genes, decreased the activity of the flavin kinase RibCF, and improved the de novo purine synthesis and pentose supply, after which the riboflavin yield reached more than $26 \mathrm{~g} / \mathrm{L}$. At present, the bottleneck of riboflavin production is mainly due to the poor genetic stability of the engineered strain, and more by-products produced by fermentation, which restrict the high yield of riboflavin.

\section{Vitamin $\mathbf{B}_{3}$}

Niacin is the precursor in the synthesis of the pyridine coenzymes NAD (nicotinamide adenine dinucleotide) and NADP (nicotinamide adenine dinucleotide phosphate) (Chand and Savitri, 2016; Chauhan and Poddar, 2019; Tannous et al., 2020). It is found at relatively high concentrations in internal organs of animal, muscle tissues, and fruits. Currently, niacin is mainly used as a feed additive to increase the utilization of feed protein, or as a pharmaceutical intermediate in the synthesis of various drugs. So far, there is no systematic description of a commercial fermentation process of nicotinic acid (NA) or nicotinamide (NAM). Industrial production methods are mainly ammonia oxidation and electrolytic oxidation, but the former has 
TABLE 1 | Water-soluble vitamins produced by biotechnological methods.

\begin{tabular}{|c|c|c|c|c|c|}
\hline Vitamins & Strains & Biotechnological method & $\begin{array}{l}\text { Medium and } \\
\text { precursor }\end{array}$ & Yield & References \\
\hline \multirow[t]{3}{*}{ Vitamin $\mathrm{B}_{1}$} & B. subtilis TH95 & $\begin{array}{l}\text { Mutation of gene encoding thiamine pyrophosphate } \\
\text { kinase activity (thiN) and thiamine-related transport } \\
\text { protein (ykoD } \\
\text { and yuaJ). }\end{array}$ & MM & $1.27 \mathrm{mg} / \mathrm{L}$ & Schyns et al., 2005 \\
\hline & E. coli & $\begin{array}{l}\text { TPP biosensor (plasmid pTPP_Bios); Overexpression of } \\
\text { native thiFSGH; thiC; thiE; and thiD; Genetic-metabolic } \\
\text { coupling. }\end{array}$ & MM & $0.80 \mathrm{mg} / \mathrm{L}$ & $\begin{array}{l}\text { Cardinale et al., } \\
2017\end{array}$ \\
\hline & A. oryzae & Overexpression of thiP, thiA, and $n m t A$. & $\begin{array}{l}\text { CD-Dex medium } \\
\text { (5\% dextrin) }\end{array}$ & 4-fold > WT & Tokui et al., 2011 \\
\hline \multirow[t]{3}{*}{ Vitamin $B_{2}$} & B. subtilis & $\begin{array}{l}\text { Decrease the activity of flavinase RibCF activity; } \\
\text { Overexpression of riboflavin biosynthetic genes; improved } \\
\text { the de novo purine synthesis and pentose supply. }\end{array}$ & MM & $>26 \mathrm{~g} / \mathrm{L}$ & $\begin{array}{l}\text { Schwechheimer } \\
\text { et al., } 2016\end{array}$ \\
\hline & A. gossypii & $\begin{array}{l}\text { Introduced the icl gene; Overexpression of gly1, prs2,4, } \\
\text { and prs3 genes; Knocked out vma4, shm2, and bas } 1 \\
\text { genes. }\end{array}$ & $\begin{array}{l}\text { YPD; } \\
\text { Plant oil }\end{array}$ & $>20 \mathrm{~g} / \mathrm{L}$ & $\begin{array}{l}\text { Abbas and Sibirny, } \\
2011\end{array}$ \\
\hline & Candida famata & $\begin{array}{l}\text { Conventional mutagenesis by overexpression of sef } 1 \text { and } \\
\text { imh3. }\end{array}$ & $\begin{array}{l}\text { YPD; } \\
\text { Fluorophenilalanine }\end{array}$ & $1026 \pm 50$ mg/L & $\begin{array}{l}\text { Dmytruk et al., } \\
2011\end{array}$ \\
\hline \multirow[t]{2}{*}{ Vitamin $\mathrm{B}_{3}$} & Yeast & $\begin{array}{l}\text { Knock out NR importer Nrt1in the NR-non-salvaging } \\
\text { genotype } n r k l, \text { urhl, pmpl (strain PAB038). }\end{array}$ & $\begin{array}{l}\text { 2x YPD; } \\
\text { Nicotinic acid }\end{array}$ & $8 \mathrm{mg} / \mathrm{L}$ & Belenky et al., 2011 \\
\hline & E. coli & Expressing R. hodochrous nitrile hydratase. & $\begin{array}{l}\text { LB medium; } \\
2 Y T \text { medium }\end{array}$ & $508 \mathrm{~g} / \mathrm{L}$ & Wang et al., 2017 \\
\hline \multirow[t]{2}{*}{ Vitamin $\mathrm{B}_{5}$} & C. glutamicum & $\begin{array}{l}\text { Deletion of ilvA gene and overexpression of ilVBNCD and } \\
\text { panBC genes }\end{array}$ & MM & 1000 mg/L & $\begin{array}{l}\text { Leonardi and } \\
\text { Jackowski, } 2007\end{array}$ \\
\hline & B. subtilis & $\begin{array}{l}\text { Overexpression of ilvBHCD and panBCDE; } \\
\text { Overexpression of SerA and GlyA of the enzymes of the } \\
\text { glycine cleavage cycle. }\end{array}$ & MM & 82-86 g/L & $\begin{array}{l}\text { Hohmann et al., } \\
2016\end{array}$ \\
\hline \multirow[t]{3}{*}{ Vitamin $\mathrm{B}_{6}$} & E. coli & Overexpression of native Epd, PdxJ, and Dxs enzymes & MM & $78 \mathrm{mg} / \mathrm{L}$ & $\begin{array}{l}\text { Hoshino et al., } \\
2004\end{array}$ \\
\hline & $\begin{array}{l}\text { S. meliloti } \\
\text { IFO14782 }\end{array}$ & Overexpression of E. coli Epd and native PdxJ enzyme. & MM & $1.30 \mathrm{~g} / \mathrm{L}$ & $\begin{array}{l}\text { Hoshino et al., } \\
2007\end{array}$ \\
\hline & B. subtilis & $\begin{array}{l}\text { Overexpression of } E \text {. coli PdxA and S. meliloti PdxJ } \\
\text { enzymes. }\end{array}$ & MM & $65 \mathrm{mg} / \mathrm{L}$ & $\begin{array}{l}\text { Commichau et al., } \\
2015\end{array}$ \\
\hline \multirow[t]{3}{*}{ Vitamin $\mathrm{B}_{7}$} & $\begin{array}{l}\text { Agrobacterium/ } \\
\text { Rhizobium HK4 }\end{array}$ & $\begin{array}{l}\text { Overexpression of a strong biotin operon from E. coli; Use } \\
\text { of a powerful artificial tac promoter and introduct of a } \\
\text { modified RBS in front of BioB. }\end{array}$ & $\begin{array}{l}\text { MM; Betaine; } \\
\text { Diaminononanoic } \\
\text { acid }\end{array}$ & $110 \mathrm{mg} / \mathrm{L}$ & $\begin{array}{l}\text { Streit and } \\
\text { Entcheva, } 2003\end{array}$ \\
\hline & E. coli & $\begin{array}{l}\text { Overexpression of native biotin operon from a high-copy } \\
\text { number plasmid }\end{array}$ & $\begin{array}{c}\text { MM; } \\
\text { H-medium }\end{array}$ & $11 \mathrm{mg} / \mathrm{L}$ & Ifuku et al., 1995 \\
\hline & B. subtilis & $\begin{array}{l}\text { Overexpression of native biotin operon and selection on } \\
S \text {-2-aminoethyl-L-cysteine. }\end{array}$ & MM & $21 \mathrm{mg} / \mathrm{L}$ & $\begin{array}{l}\text { Van Arsdell et al., } \\
2005\end{array}$ \\
\hline Vitamin $\mathrm{B}_{9}$ & $\begin{array}{l}\text { A. gossypii } \\
\text { (ATCC 10895) }\end{array}$ & $\begin{array}{l}\text { Overexpression of FOL genes and deletion of } A g M E Y 7 \text {; } \\
\text { Deletion of } A g A D E 12 \text { and } A g R I B 1 \text { at the same time. }\end{array}$ & MA2 rich medium & $7 \mathrm{mg} / \mathrm{L}$ & $\begin{array}{l}\text { Serrano-Amatriain } \\
\text { et al., } 2016\end{array}$ \\
\hline \multirow[t]{4}{*}{ Vitamin $\mathrm{B}_{12}$} & $\begin{array}{l}\text { S. meliloti } \\
\text { (MC5-2) }\end{array}$ & $\begin{array}{l}\text { High throughput screening of mutants using riboswitch } \\
\text { ARTP-irradiation was used to induce random mutations; } \\
\text { Deletion of cobl; Overexpression of hemE. }\end{array}$ & $\begin{array}{l}\text { MM; } \\
\text { Cobalt chloride; } \\
\text { DMBI }\end{array}$ & $156 \pm 4.20 \mathrm{mg} / \mathrm{L}$ & Cai et al., 2018 \\
\hline & P. denitrificans & $\begin{array}{l}\text { Random mutagenesis and genetic engineering; } \\
\text { Overexpression of cobF-cobM gene cluster and } \operatorname{cog} A \\
\text { and cobE genes; Optimize the best } \mathrm{PH} \text { range; Optimize } \\
\text { promoters. }\end{array}$ & $\begin{array}{l}\text { Betaine; Beet } \\
\text { molasses; } \\
\text { Choline chloride }\end{array}$ & $214.30 \mathrm{mg} / \mathrm{L}$ & Li et al., 2008 \\
\hline & E. coli & $\begin{array}{l}\text { Heterologously expressed the hemO, hemB, hemC, and } \\
\text { hemD genes etc.; Optimizing of fermentation conditions. }\end{array}$ & CM medium & $0.67 \mathrm{mg} / \mathrm{L}$ & Fang et al., 2018 \\
\hline & $\begin{array}{l}\text { Propionibacterium } \\
\text { shermanii }\end{array}$ & Overexpression of biosynthetic genes. & $\begin{array}{l}\mathrm{MM} ; \\
\mathrm{DMBI}\end{array}$ & 206 mg/L & Sych et al., 2016 \\
\hline \multirow[t]{2}{*}{ Vitamin C } & $\begin{array}{l}\text { S. cerevisiae and } \\
\text { Zygosaccharomyces } \\
\text { bailii }\end{array}$ & $\begin{array}{l}\text { Overexpressing the endogenous D-arabinono-1,4-lactone } \\
\text { oxidase and L-galactose dehydrogenase } \\
\text { (overexpression of lgdh and alo1). }\end{array}$ & $\mathrm{MM}$ & $100 \mathrm{mg} / \mathrm{L}$ & Sauer et al., 2004 \\
\hline & $\begin{array}{l}\text { K. vulgare DSM } \\
4025\end{array}$ & Oxidation and lactonization. & $\begin{array}{l}\text { L/D-sorbose; } \\
\text { Glycerol; } \\
\text { Baker's yeast }\end{array}$ & $1.37 \mathrm{~g} / \mathrm{L}$ & $\begin{array}{l}\text { Sugisawa et al., } \\
2005\end{array}$ \\
\hline
\end{tabular}


TABLE 1 | Continued

\begin{tabular}{|c|c|c|c|c|c|}
\hline Vitamins & Strains & Biotechnological method & $\begin{array}{l}\text { Medium and } \\
\text { precursor }\end{array}$ & Yield & References \\
\hline & X. campestris 2286 & $\begin{array}{l}\text { Lactonation under oxidative stress; } \\
\text { Direct synthesis of glucose (carbohydrate source) } \\
\text { induced by free radicals (HOCL treatment). }\end{array}$ & $\begin{array}{c}\mathrm{MM} ; \mathrm{K}_{2} \mathrm{HPO}_{4} \\
\text { Urea }\end{array}$ & $20.40 \mathrm{~g} / \mathrm{L}$ & $\begin{array}{l}\text { Rao and } \\
\text { Sureshkumar, } 2000\end{array}$ \\
\hline & $\begin{array}{l}\text { G. oxydans and } \\
\text { K. vulgare and } \\
\text { B. endophyticus }\end{array}$ & $\begin{array}{l}\text { Cell-cell interaction; } \\
\text { One step 2-KGA fermentation. }\end{array}$ & D-sorbitol & $\begin{array}{c}73.70 \mathrm{~g} / \mathrm{L} \\
(2-\mathrm{KGA})\end{array}$ & Ma et al., 2019 \\
\hline
\end{tabular}

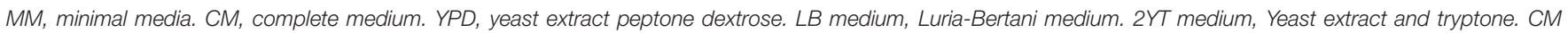
medium, Cramer-Myers medium. DMBI, 5,6-dimethylbenzimidazole. YD, yeast extract and glucose. MYGP, malt extract, yeast extract, peptone, agar and dextrose.

high production costs and needs to be above $300^{\circ} \mathrm{C}$ during the reaction, and the latter has low costs of production, however, the efficiency of electrolysis is not high, which limits the industrial production of niacin (Chand and Savitri, 2016).

Recent reports describe the use of recombinant E. coli expressing Rhodococcus rhodochrous nitrile hydratase for vitamin $\mathrm{B}_{3}$ production. At low cell density, nicotinamide was produced in fed-batch mode, and the product concentration reached $390 \mathrm{~g} / \mathrm{L}$. After high-density culture in $5 \mathrm{~L}$ bioreactor, the concentration of nicotinamide reached $508 \mathrm{~g} / \mathrm{L}$ in $60 \mathrm{~min}$ (Figure 1D; Wang et al., 2017). Belenky et al. (2011) showed that the disruption of $n r t 1$ results in increased export of nicotinamide riboside (NR). Moreover, disruption of the niacin transporter Tnal can also increase the output of niacin, revealing that cells regulate the intracellular $\mathrm{NAD}^{+}$metabolic process by balancing the transport of niacin, the precursor of $\mathrm{NAD}^{+}$. On the basis of adding $5 \mathrm{mM}$ niacin, yeast cells can produce $8 \mathrm{mg} / \mathrm{L}$ nicotinamide mononucleotide (Belenky et al., 2011).

\section{Vitamin $\mathrm{B}_{\mathbf{5}}$}

Vitamin $\mathrm{B}_{5}$, also known as pantothenic acid, is composed of pantoic acid and $\beta$-alanine $(\beta$-Ala), which is a precursor of coenzyme A (Leonardi and Jackowski, 2007). It plays an important role in maintaining the health of skin and blood. Its general function is to participate in the production of energy in the body, but it can also control the fat metabolism, and is also an essential nutrient for the brain and nerves. There are chemical and microbial synthesis methods for the synthesis of pantothenic acid, whereby microbial methods can be used to directly synthesize optically pure D-pantothenic acid.

Sahm and Eggeling (1999) adopted a series of methods to increase the production of pantothenic acid, including the deletion of the ilvA gene and the overexpression of the ilvBNCD and panBC genes. The pantothenic acid production of the best strain reached $1000 \mathrm{mg} / \mathrm{L}$ (Figure 1F; Sahm and Eggeling, 1999). Huser et al. (2005) also used Corynebacterium glutamicum to produce pantothenic acid. They deleted the ilvA gene, inhibited the expression of the $i l v E$ gene and overexpressed the $i l v B N C D$ gene. The final titer of pantothenate reached $1.75 \mathrm{~g} / \mathrm{L}$ (Huser et al., 2005). Studies have shown that the specific activity of pantothenic acid synthase PanC of C. glutamicum is $205.10 \mathrm{U} / \mathrm{mg}$. Adding substrates (D-pantothenic acid and $\beta$-Ala) to E. coli containing the enzyme can be produced $97.10 \mathrm{U} / \mathrm{mg}$ within $32 \mathrm{~h}$, the conversion rate of pantothenic acid was $99.10 \%$.
However, the reported work had production defects, which required the addition of exogenous substrate pantothenic acid, and the high market price of pantothenic acid seriously restricted the industrialization of this method. Another chassis organism that is commonly used to produce pantothenic acid is B. subtilis. Hohmann et al. (2016) clarified the highest production of pantothenic acid by overexpressing ilvBHCD, panBCDE, serA, and $g l y A$, as well as the enzymes of the glycine cleavage cycle the purpose is to increase the number of precursors for pantothenic acid synthesis (Figure 1F). The maximal output of the best strain reached 82-86 g/L during a $48 \mathrm{~h}$ fed-batch fermentation, opening up a new chapter of vitamin production in the biological world (Hohmann et al., 2016).

\section{Vitamin $\mathrm{B}_{6}$}

There are six forms of vitamin $\mathrm{B}_{6}$, including pyridoxine (PN), pyridoxal (PL), and pyridoxamine (PM), as well as their respective phosphate derivatives. It is a water-soluble vitamin, which exists in the form of phosphate in the body. The most versatile form of vitamin $\mathrm{B}_{6}$ is pyridoxal $5^{\prime}$-phosphate (PLP), which is a cofactor of many proteins and enzymes in all organisms. As the most widely available commercial form, PN hydrochloride is extensively used in the pharmaceutical and food industries (Eliot and Kirsch, 2004).

Two de novo synthesis routes have been reported the 1deoxyxylulose 5-phosphate (DXP)-dependent pathway and the DXP-independent pathway (Tanaka et al., 2005). From largescale screening studies of different strains, found that the Gramnegative bacterium Sinorhizobium meliloti is the best producer of vitamin $\mathrm{B}_{6}$, reaching a titer of $103 \mathrm{mg} / \mathrm{L}$ of $\mathrm{B}_{6}$ isoforms within $168 \mathrm{~h}$. Vitamin $\mathrm{B}_{6}$ production was further increased to $1.30 \mathrm{~g} / \mathrm{L}$ by expressing the $E$. coli epd gene and the native $d x$ s gene in this S. meliloti strain (Figure 1E; Hoshino et al., 2007). E. coli and $B$. subtilis were also engineered to produce vitamin $\mathrm{B}_{6}$. The vitamin $\mathrm{B}_{6}$ production was enhanced to $78 \mathrm{mg} / \mathrm{L}$ within $31 \mathrm{~h}$ in E. coli, and B. subtilis produced $65 \mathrm{mg} / \mathrm{L}$ of $\mathrm{PN}$ when supplied with the precursor 4-hydroxy-L-threonine (4HT) (Hoshino et al., 2004). At present, the industry mainly adopts the oxazole method to produce vitamin $\mathrm{B}_{6}$, and the current research also focuses on the improvement of the oxazole method synthesis process. In the process of biosynthesis, the PdxJ enzyme activity is very low $\left(k_{\text {cat }}=0.07 \mathrm{~s}^{-1}\right)$, and the reaction step catalyzed by this enzyme is the rate-limiting step in the $\mathrm{VB}_{6}$ biosynthetic pathway. The intermediate metabolite 4-phosphate hydroxy-threonine (4HTP) 


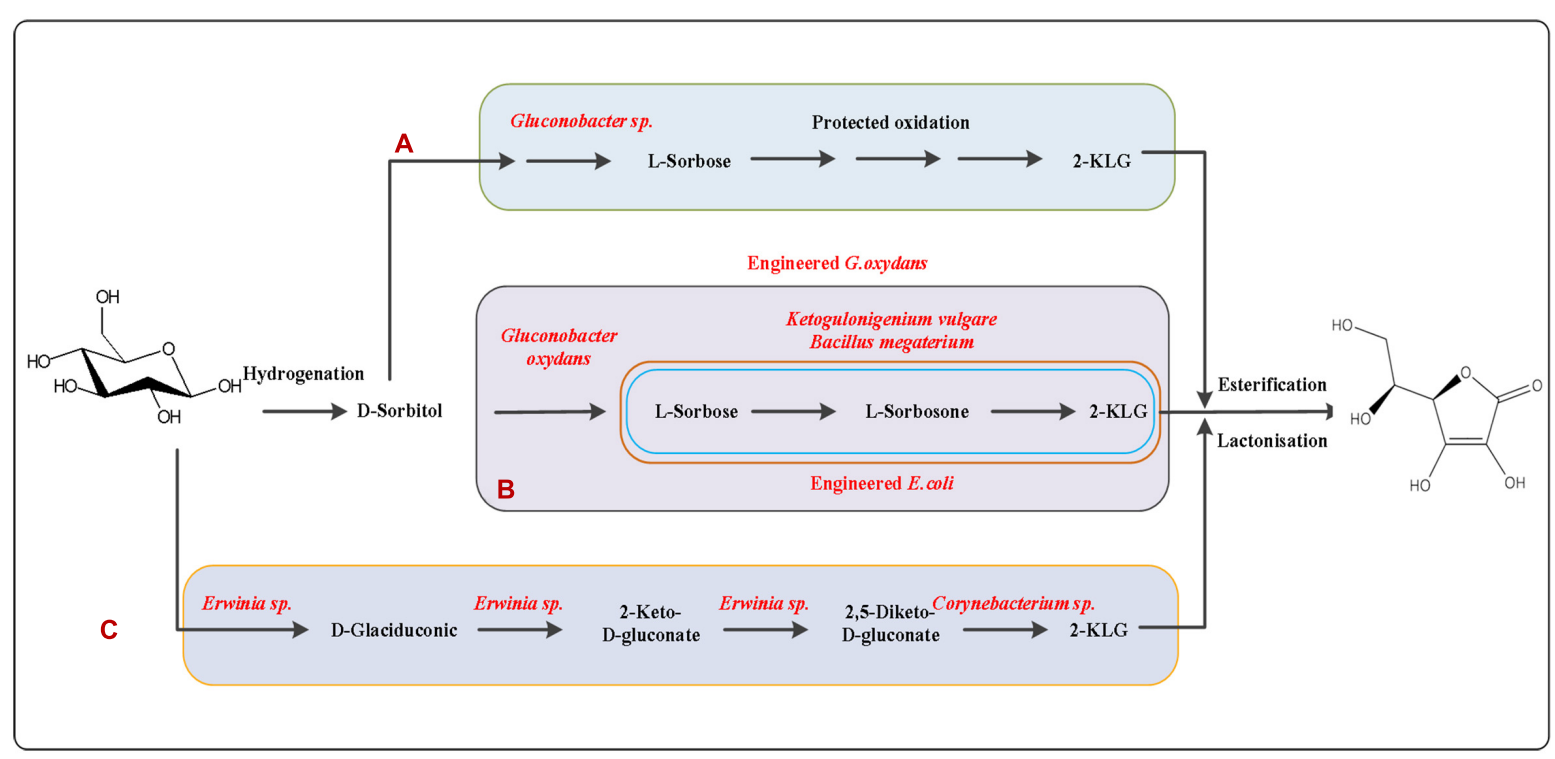

FIGURE 2 | L-ascorbic acid production pathway. (A) Classical Reichstein process: the seven-step Reichstein process involving six chemical transformations and one fermentation by Gluconobacter oxydans. (B) Two steps fermentation by mixed bacteria: G. oxydans, Bacillus megaterium and Ketogulonicigenium vulgare; (C) 2,5-Diketo-D-gluconic acid pathway: mixed or two stage fermentations with Erwinia sp. and Corynebacterium sp. or other species for the direct synthesis of 2-KLG.

is cytotoxic and is also the main bottleneck of biosynthesis. Therefore, the fermentative production of vitamin $B_{6}$ requires more effort to meet the commercial demand.

\section{Vitamin $\mathrm{B}_{\mathbf{7}}$}

Biotin is indispensable for the normal metabolism of fats and proteins (Lin and Cronan, 2011; Selvam et al., 2019). It is a nutrient necessary for human growth, development and normal function. Biotin combines with enzymes to participate in the process of carbon dioxide fixation and carboxylation in the body. The current large-scale production of D-biotin is mainly based on the Sternbach synthetic route, and the current industrial production method were improved on this basis. Unless biosynthetic methods can obtain high output at low cost, it is difficult to shake the position of chemical synthesis technology in industrial production. Nevertheless, it was recently reported that some microorganisms can overproduce biotin, which has been elaborated in C. glutamicum, Mesorhizobium loti, and S. meliloti.

In Agrobacterium and Rhizobium HK40, overexpression of the biotin operon from $E$. coli driven by the powerful tac promoter and introducing a modified RBS in front of bioB resulted in a biotin yield of $110 \mathrm{mg} / \mathrm{L}$ (Figure 1G; Streit and Entcheva, 2003). If the native biotin operon is overexpressed in B. subtilis, most enzymes will be strongly inhibited by the by-product of SAM. However, the high demand for SAM by biotin synthase and 7,8diaminononanoate synthase is still a bottleneck that must be addressed in future research. If lysine is supplied to B. subtilis, BioK will use lysine as the amino donor of the biotin precursor to promote the production of biotin precursor (dephosphorization biotin), and the fermentation process used carbon-limited fedbatch growth conditions with computer control of dissolved oxygen concentrations, but the maximal titer can only reach
$21 \mathrm{mg} / \mathrm{L}$ biotin. Therefore, improving the catalytic mechanism of biotin synthase is also a challenge for future research (Van Arsdell et al., 2005; Lin and Cronan, 2011).

\section{Vitamin $\mathrm{B}_{\mathbf{9}}$}

Naturally occurring folic acid is mostly found in the form of polyglutamic acid, and the biologically active form of folic acid is tetrahydrofolate (Myszczyszyn et al., 2019). Deficiency can lead to reduced hemoglobin content in red blood cells, impaired cell maturation and megaloblastic anemia (Lucock, 2000). B. subtilis or A. gossypii were successfully engineered to produce folic acid.

Jagerstad and Jastrebova (2013) achieved a 5methyltetrahydrofolate (THF) titer of $0.95 \mathrm{mg} / \mathrm{L}$ by increasing the supply of precursor substances and blocking the catabolic pathway of THF in B. subtilis. With the continuous research progress, A. gossypii has attracted increasing interest as the chassis strain for folic acid production. A. gossypii can synthesize $0.04 \mathrm{mg} / \mathrm{L}$ of folic acid naturally, which can reach $6.59 \mathrm{mg} / \mathrm{L}$ after metabolic engineering treatment. This is also the highest production value reported to date (Figure 1C; Serrano-Amatriain et al., 2016). Since the commercial chemical synthesis of folic acid is cheap, unless the environmentally unfriendly part of the chemical synthesis process is restricted, there is still a long way to go for the fermentation of this product.

\section{Vitamin $\mathrm{B}_{\mathbf{1 2}}$}

Cobalamin is the only vitamin containing metal elements. Cobalamin is the general term for a class of corrin compounds containing cobalt (Osman et al., 2021). It is the largest and most complex vitamin molecule discovered so far. Vitamin $B_{12}$ deficiency leads to increased formation of ring sideroblasts in pre-myelodysplastic syndromes (Kitago et al., 2020). 
Vitamin $\mathrm{B}_{12}$ is synthesized by microorganisms through de novo synthesis or salvage synthesis in nature, but higher-animals and plants cannot produce it (Figure 1H; Fang et al., 2017). Although in the 19th century, researchers have completed the full chemical synthesis of vitamin $B_{12}$, the chemical synthesis method is too complicated and expensive, so the world's major suppliers rely on microbial fermentation to produce vitamins. Pseudomonas denitrificans and Propionibacterium freudenreichii being widely used in industrial fermentation to produce vitamin $\mathrm{B}_{12}$. In order to improve the productivity of vitamin $\mathrm{B}_{12}$, researchers have adopted a random mutagenesis method to construct a vitamin $\mathrm{B}_{12}$ overproducing strains by ultraviolet rays, nitrosoguanidine (NTG), nitrosomethylurethane and ethyleneimine (Blanche et al., 1992, 1995a,b). Propionibacterium shermanii was reported to produce vitamin $\mathrm{B}_{12}$ with a maximum titer of $200 \mathrm{mg} / \mathrm{L}$ (Sych et al., 2016). However, the aerobic $P$. denitrificans remains the most used industrial host, and the effect is obvious. Moreover, $P$. denitrificans has stronger production capacity than the anaerobic strain that produces vitamin $\mathrm{B}_{12}$ and is widely used in industrial production. Xia et al. (2015) increased the production of vitamin $B_{12}$ to $198 \pm 4.60 \mathrm{mg} / \mathrm{L}$ by optimizing the fermentation medium using response surface method. Our research group used E. coli strain MG1655 (DE3) as the starting strain to achieve de novo synthesis of vitamin $\mathrm{B}_{12}$ (Fang et al., 2018). Cai et al. (2018) later used riboswitch elements in S. meliloti for the first time, and successfully developed a flow cytometry highthroughput screening system for high-yield $\mathrm{VB}_{12}$ strains. The vitamin $\mathrm{B}_{12}$ titer of the best strain, $S$. meliloti MC5-2, reached $156 \pm 4.20 \mathrm{mg} / \mathrm{L}$, but the yield was still relatively low. At the same time, they also emphasized that the titer of vitamin $B_{12}$ is greatly dependent on the medium composition (Cai et al., 2018).

\section{Vitamin C}

Vitamin C, also known as L-ascorbic acid (LAA), is an important cofactor for multiple enzyme reaction in the body (Paciolla et al., 2019; Kawahori et al., 2020). It can act as an antioxidant to scavenge free radicals and reduce oxidative stress, so a rapidly expanding market is the application of LAA as an additive to cosmetic products (Timoshnikov et al., 2020). Vitamin C deficiency can result in scurvy. Recently, researchers used biochemical methods combined with DNA recombination technology to produce vitamin $\mathrm{C}$.

At present, L-AA is commercially manufactured via the classic seven-step Reichstein process using D-glucose as the initial substrate. The process involves six chemical steps and one fermentation steps for the oxidation of D-sorbitol to 2-keto-Lgulonic acid (2-KGA) by Gluconobacter oxydans and Bacillus megaterium (Figure 2A). Sugisawa et al. (2005) reported for the first time that Ketogulonigenium vulgare DSM 4025 can produce $1.37 \mathrm{~g} / \mathrm{L}$ of L-AA under static culture conditions. Kim et al. $(1996,1998)$ reported that the respective enzymes from Candida albicans and S. cerevisiae convert not only D-arabinose to Darabinono-1,4-lactone but also L-galactose to L-galactono-1,4lactone in vitro. Experiments have shown that budding yeast cells overexpressing the endogenous D-arabinono-1,4-lactone oxidase and L-galactose dehydroge-nase can produce about $100 \mathrm{mg} / \mathrm{L}$ of
L-ascorbic acid (Sauer et al., 2004). A microbiological consortium composed of G. oxydans, K. vulgare, and B. endophyticus was constructed to produce $2-\mathrm{KGA}$, and a final yield of $73.70 \mathrm{~g} / \mathrm{L}$ was obtained within $30 \mathrm{~h}$ (Figure 2B; Ma et al., 2019). This result holds promise for the construction of a microbial cell factory for the production of vitamin C. However, it has been reported that mixed-bacteria fermentation can be unstable due to competition between the individual strains for nutrients and other factors. Therefore, mixed-bacteria fermentation technology has poor stability and low efficiency, which also hinders the pace of industrial production of vitamin C. Nevertheless, fermentation is expected to become the mainstream way of vitamin $\mathrm{C}$ production in the future if stable single strains can be used instead of mixed bacteria fermentation, while also shortening the production cycle.

\section{FAT-SOLUBLE VITAMINS}

\section{Vitamin A}

Vitamin A mainly includes $\beta$-carotene, $\alpha$-carotene, and $\beta$-cryptoxanthin (Wise et al., 2021). $\beta$-carotene, a provitamin A carotenoid, is divided into all-trans and cis isomers (Yang et al., 2021). All-trans- $\beta$-carotene is the major isomer found in unprocessed carotene-rich plant foods, followed by its 9and 13-cis isomers. $\beta$-carotene is an antioxidant, which not only inhibits singlet oxygen but also inhibits lipid peroxidation, thereby playing an important role in the prevention of disease (Kawata et al., 2018).

Carotene is mainly produced by fungi, some bacteria, and algae. For example, Yoon et al. increased the supply of IPP (isopentenyl diphosphate) and DMAPP (dimethylallyl diphosphate) through the introduction of foreign MVA (mevalonate) pathway (Figure 3D), thereby enhancing the production of carotenoids. The final engineered E. coli with a whole MVA pathway and $\beta$-carotene synthesis gene can produce $\beta$-carotene of $465 \mathrm{mg} / \mathrm{L}$ (Figure 3C; Yoon et al., 2009). Adenosine-triphosphate (ATP) and nicotinamide adenine dinucleotide phospha (NADPH) are two important cofactors in $\beta$-carotene biosynthesis pathway. Zhao et al. (2013) used E. coli as host cells, constructed and optimized a central metabolic module to increase the supply of ATP and NADPH in $\beta$ carotene synthesis pathway, thereby improving the yield of the $\beta$-carotene. Finally, the best strain CAR005 increased the $\beta$-carotene production to $2.1 \mathrm{~g} / \mathrm{L}$ with a yield of $60 \mathrm{mg} / \mathrm{g}$ DCW in fed-batch fermentation (Zhao et al., 2013). Larroude et al. (2018) overexpressed heterologous carotene synthase (Crt) in Yarrowia lipolytica to make it produce high $\beta$-carotene. The fermentation yield of the engineered strain obtained by screening the best promoter was $1.5 \mathrm{~g} / \mathrm{L}$. By optimizing the fermentation conditions and using fed-batch fermentation, the yield of $\beta$-carotene was further increased production titer of $6.5 \mathrm{~g} / \mathrm{L}$ and $90 \mathrm{mg} / \mathrm{g}$ DCW (Larroude et al., 2018). However, the insufficient number of precursors seriously hindered the industrialization process of $\beta$-carotene in the process of $\beta$-carotene synthesis in the future. 


\section{Vitamin D}

Vitamin D refers to a group of fat-soluble secosteroids responsible for increasing intestinal absorption of magnesium, calcium, and phosphate, and many other biological effects. The most important compounds are vitamin $\mathrm{D}_{2}$ (ergocalciferol) and vitamin $\mathrm{D}_{3}$ (cholecalciferol) in vitamin $\mathrm{D}$. Vitamin $\mathrm{D}$ can increase intestinal absorption of calcium, magnesium, and phosphate, and can prevent many diseases (Yuan et al., 2020).

It is well known that the precursor of vitamin $\mathrm{D}_{2}$ is ergosterol (Papoutsis et al., 2020). Vitamin $\mathrm{D}_{2}$ is widely used in medical, food and other industries. The current commercial production of ergosterol is mainly produced by yeast fermentation. Tan et al. improved the production of ergosterol by optimizing the fermentation medium and screening high ergosterol producing strains (Figure 3F). The results show that dissolved oxygen (DO) can be used as the effective control parameter for yeast fedbatch fermentation. The total yield of ergosterol can be increased to $1.16 \mathrm{~g} / \mathrm{L}$ when DO was controlled at $12 \%( \pm 1 \%)$ and pulse fed-batch was used (Tan et al., 2003).

Vitamin $\mathrm{D}_{3}$ cannot play a direct role in human and animals, but it can produce the physiologically active form 25hydroxyvitamin $\mathrm{D}_{3}\left(25-\mathrm{OH}-\mathrm{VD}_{3}\right)$ through the metabolism in liver. At present, the production process of $25-\mathrm{OH}-\mathrm{VD}_{3}$ mainly includes chemical synthesis and light irradiation. The chemical reaction steps are cumbersome, some of them need halogen reagents, and the racemates are generated during the reaction, which makes the separation difficult. Therefore, more and more researchers pay attention to the fermentation of $25-\mathrm{OH}-\mathrm{VD}_{3}$ by microorganisms. The strains used in microbial biosynthesis mainly include Rhodococcus, Streptomyces, Pseudonocardia sp., and Mycobacterium. Vitamin $\mathrm{D}_{3}$ hydroxylase ( $\mathrm{Vdh}$ ) is a kind of cytochrome P450 monooxygenase, which can catalyze the twostep hydroxylation of vitamin $\mathrm{D}_{3}\left(\mathrm{VD}_{3}\right)$ to produce $25-\mathrm{OH}-\mathrm{VD}_{3}$ and $1 \alpha, 25$-dihydroxyvitamin $\mathrm{D}_{3}$. Yasutake et al. (2013) used nisin, a natural bioactive antimicrobial peptide, to treat Rhodococcus cells containing hydroxylase, and they found that $573 \mathrm{mg} / \mathrm{L} \mathrm{25-}$ $\mathrm{OH}-\mathrm{VD}_{3}$ can be synthesized. Although the current industrial production of vitamin $\mathrm{D}_{3}$ is mainly dominated by chemical synthesis, microbial synthesis methods are more sustainable and do not produce impurities during the biosynthesis process, thus it will be taken priority in the future industrial production.

\section{Vitamin E}

Vitamin E is a group of lipid-soluble antioxidants, including tocopherols and tocotrienols (Muñoz and Munné-Bosch, 2019; Zeng Z. et al., 2020). These compounds are composed of an oxygen-containing double ring system with a hydrophobic prenyl side chain (Blake and Konings, 2019). Lack of vitamin $\mathrm{E}$ affects the function of $\mathrm{T}$ and $\mathrm{B}$ immune cells (Moriguchi and Muraga, 2000). Additionally, patients with severe impairment due to Alzheimer's disease improved significantly after receiving $\alpha$-tocopherol (Sano et al., 1997). Considering various physiological effects of tocopherols, they are widely used in the manufacture of human dietary supplements, food preservatives and cosmetics. There are four different tocopherol compounds, named $\alpha, \beta, \gamma$, and $\delta$ tocopherol. Among the four forms of vitamin $\mathrm{E}, \alpha$-tocopherol is the most biologically active (Kaiser et al., 1990). In nature, $\alpha$-tocopherol is produced by photosynthetic organisms, e.g., eukaryotic algae and green plants, some prokaryotic cyanobacteria, such as Synechocystis, which can accumulate vitamin E in large amounts (Figure 3B; Taketomi et al., 1983).

Recently, Euglena gracilis was found to be suitable for the production of high-value products, such as amino acids and ascorbic acid (Schwarzhans et al., 2015). E. gracilis is the most promising host for the commercial production of $\alpha$-tocopherol, with a high growth rate and $\alpha$-tocopherol content, which accounts for more than $97 \%$ of the total tocopherol accumulated by E. gracilis. Tani and Tsumura added precursors such as homogentisate and L-tyrosine to E. gracilis growth medium, which increased the accumulation of $\alpha$-tocopherol to $143.60 \mathrm{mg} / \mathrm{L}$ corresponding to $5.1 \mathrm{mg} / \mathrm{g}$ dry cell weight (DCW) (Tani and Tsumura, 1989). Durmaz (2007). explored the effect of nitrogen source and concentration on the accumulation of $\alpha$-tocopherol in Nannochloropsis oculata. When sodium nitrate and ammonium chloride were used as inorganic nitrogen source, the highest content of $\alpha$-tocopherol reached $2.32 \pm 0.04 \mathrm{mg} / \mathrm{g}$ dry weight (DW) (Table 2). The research showed that higher concentrations of nitrogen in the form of $\mathrm{NO}_{3}{ }^{+}$and $\mathrm{NH}_{4}{ }^{+}$can promote production the of $\alpha$-tocopherol (Durmaz, 2007).

To balance cell growth and product synthesis, Shen et al. (2020) recently combined heterologous genes from photosynthetic organisms with the endogenous shikimate and mevalonate pathways (MEP) to construct a strain of $S$. cerevisiae that produces tocotrienols (Figure 3A). By incorporating a newly designed cold-shock-triggered temperature control system, the phased control of cell biomass and tocotrienol accumulation by the engineered strains was successfully realized. The final total tocotrienol titer reached $320 \mathrm{mg} / \mathrm{L}$ in a $5 \mathrm{~L}$ fermenter, which laid the foundation for the production of natural vitamin $\mathrm{E}$ in a fully fermentative process (Figure 3B; Shen et al., 2020).

In general, compared with chemical total synthesis, the method of obtaining vitamin E directly through biotechnology has low yield and high cost, and is not suitable for large-scale production. Although chemical total synthesis is currently the main production method of vitamin E, there are still many problems with this technology, such as complex synthesis routes, high technical barriers, etc. Therefore, the development of safer and more efficient synthesis technology has become the main problem to improve the current situation of vitamin $\mathrm{E}$.

\section{Vitamin K}

Vitamin $\mathrm{K}$ is a fat-soluble vitamin, which also called blood coagulation vitamin in virtue of the function of promoting blood coagulation and preventing osteoporosis (Henrik, 1973; Schwalfenberg, 2017; Zhou et al., 2019). There are two naturally occurring types of vitamin $\mathrm{K}$, called vitamin K1 (phylloquinone/phytomenadione) and vitamin K2 (menaquinone, MK) (Holvik et al., 2019). Vitamin K1 is synthesized by plants, while vitamin $\mathrm{K} 2$ is synthesized by microorganisms and can be divided into 14 isoforms depending on the number of isoprenoid units connected to the menaquinone ring (Figure 3E; Schwalfenberg, 2017). Among 


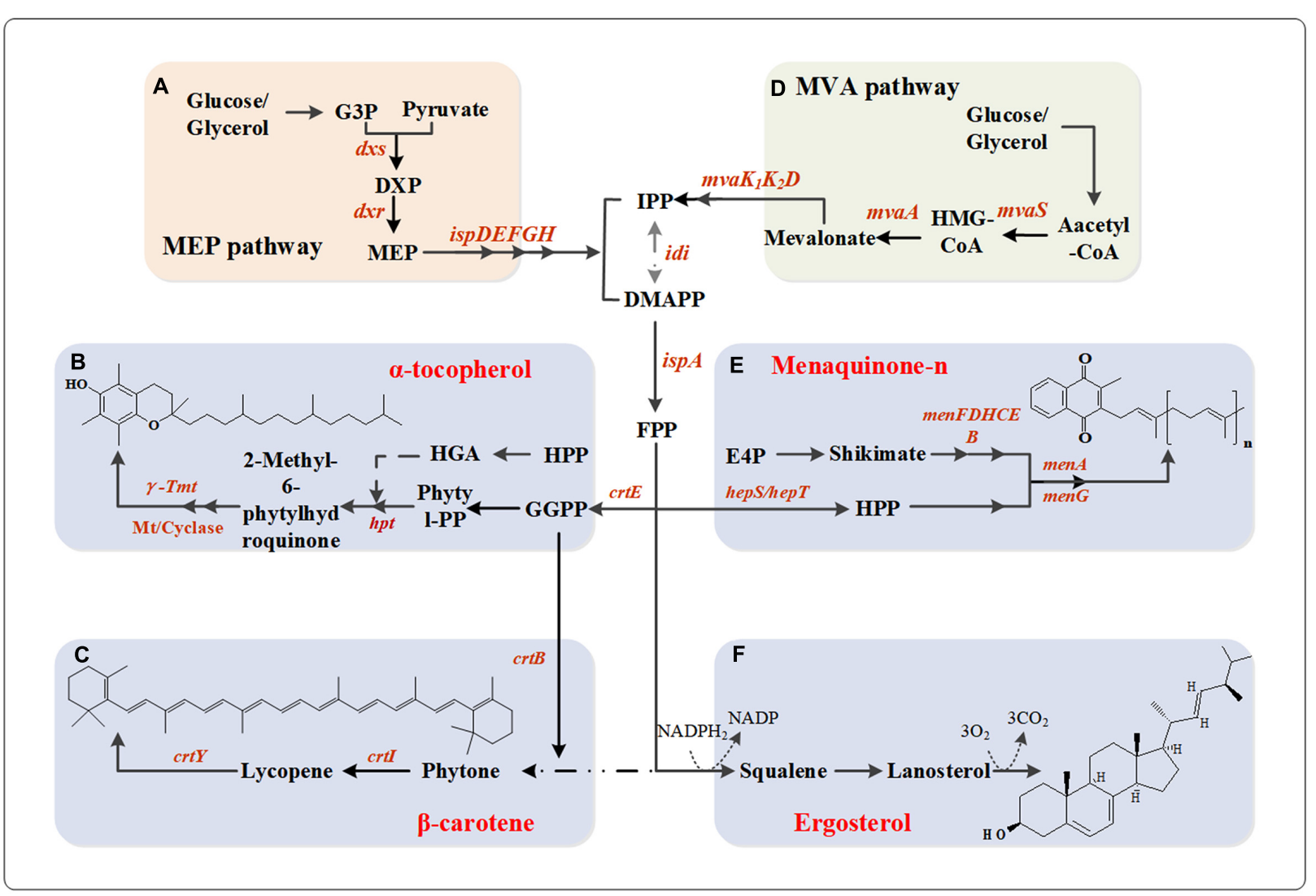

FIGURE 3 | Metabolic network pathway of vitamin A/D/E and vitamin K. (A) MEP pathway. Dxs, 1-deoxy-D-xylulose-5-phosphate synthase; Dxr, 1-deoxy-D-xylulose-5-phosphate reductoisomerase; IspD, 2-C-methyl-D-erythritol 4-phosphate cytidylyltransferase; IspE,

4-diphosphocytidyl-2-C-methyl-D-erythritol kinase; IspF, 2-C-methyl-D-erythritol 2,4-cyclodiphosphate synthase; IspG, 1-hydroxy-2-methyl-2-(E)-butenyl 4-diphosphate synthase; IspH, 4-hydroxy-3-methylbut-2-enyl diphosphate reductase; (B) $\alpha$-tocopherol biosynthesis pathway. Idi, isopentenyl diphosphate isomerase; IspA, geranyltranstransferase; CrtE, GGPP synthase; hpt, hypoxanthine phosphoribosyltransferase; $\gamma$-Tmt, $\gamma$-tocopherol methyl-transferase; Mt, methyl-transferase. (C) $\beta$-carotene biosynthesis pathway. CrtB, phytoene synthase; Crtl, phytoene desaturase; CrtY, lycopene cyclase. (D) MVA pathway. MvaS, HMG-CoA synthase; MvaA, HMG-CoA reductase; MvaK1, mevalonate kinase; MvaK2, phosphomevalonate kinase; MvaD, diphosphomevalonate decarboxylase; (E) Menaquinone-n biosynthesis pathway. HepS/HepT, heptaprenyl diphosphate synthase component I/II; MenF, isochorismate synthase; MenD,

2-succinyl-5-enolpyruvyl-6-hydroxy-3-cyclohexene-1-carboxylate synthase; $\mathrm{MenH}$, demethylmenaquinone methyltransferase; MenC, o-succinylbenzoate synthase; MenE, o-succinylbenzoate-CoA ligase; MenB, 1,4-dihydroxy-2-naphthoyl-CoA synthase; MenA, 1,4-dihydroxy-2-naphthoate heptaprenyltransferase; MenG,

demethylmenaquinone methyltransferase. (F) Ergosterol biosynthesis pathway.

them, menaquinone-7 (MK-7) is the most effective subtype of vitamin $\mathrm{K}$ with a very long half-life in circulation. Notably, MK-7 can be synthesized in the cis, trans, and cis/trans forms, but only the all-trans form is biologically active (Szterk et al., 2018).

The biosynthesis of MK-7 from the embden-meyerhofparnas (EMP) pathway, pentose phosphate pathway (PPP), MVA pathway and menadione synthesis (MK) pathway (Figure 3C). A number of microorganisms have been used to produce MK7, including B. subtilis, E. coli, lactic acid bacteria, Flavobacterium sp., and B. amyloliquefaciens (Sharma et al., 1993; Morishita et al., 1999; Sato et al., 2001; Wu, 2011; Taguchi et al., 2014).

Bacillus subtilis isolated from natto (a traditional Japanese food), the strain found in the eponymous fermented Japanese beans, has been certified by the FDA as a food-safe and has a strong ability to produce MK-7. Accordingly, B. subtilis natto was used as a parent strain to develop some of the industrial strains currently on the market. In industrial production, B. subtilis natto fermentation broth was sprayed and dried, and the dry powder from the fermentation broth was subjected to solvent extraction. The obtained extract was condensed into a paste and then purified by chromatography. Using this process, the final yield of MK-7 can reach 200-300 mg/L in the fermentation cycle of 16-24 h (Chen et al., 2016).

Cui et al. (2019) developed a bifunctional quorum-sensing system in B. subtilis 168 to engineer the synthesis modules of MK-7. The resulting strain was capable of producing $360 \mathrm{mg} / \mathrm{L}$ MK-7 in shak flasks and $200 \mathrm{mg} / \mathrm{L} \mathrm{MK-7} \mathrm{in} \mathrm{15-L} \mathrm{bioreactor} \mathrm{(Cui}$ et al., 2019). Recently, comparative transcriptomics revealed that cell membrane and electron transfer engineering in B. subtilis can improve the synthesis of $\mathrm{MK}-7$. The resulting strain reached a product titer of $410 \mathrm{mg} / \mathrm{L}$ after 6 days in shake-flask culture, which is the highest value reported to date (Cui et al., 2020). In the current market environment, the production of natural all-trans MK-7 is via liquid fermentation of B. subtilis 
TABLE 2 | Fat-soluble vitamins produced by biotechnological methods.

\begin{tabular}{|c|c|c|c|c|}
\hline Strain & Biotechnological method & Main culture substances & Yield & References \\
\hline \multicolumn{5}{|l|}{ Vitamin A } \\
\hline E. coli & $\begin{array}{l}\text { Glycerol as the carbon source and harboring the whole } \\
\text { MVA pathway. }\end{array}$ & $\begin{array}{l}\text { 2YT medium; } \\
\text { Glycerol }\end{array}$ & $465 \mathrm{mg} / \mathrm{L}$ & Yoon et al., 2009 \\
\hline E. coli & $\begin{array}{l}\text { Overexpression of crt genes, } d x s, i d i, s u c A B \text {, sdhABCD, } \\
\text { and talB. }\end{array}$ & LB medium & $2.1 \mathrm{~g} / \mathrm{L}$ & Zhao et al., 2013 \\
\hline Y. lipolytica & $\begin{array}{l}\text { Expressing the heterologous pathway and screen the best } \\
\text { combination of promoters for each of the studied genes. }\end{array}$ & $\begin{array}{l}\text { YPD medium; } \\
\text { MM medium; } \\
\text { YNB medium }\end{array}$ & $6.5 \mathrm{~g} / \mathrm{L}$ & $\begin{array}{l}\text { Larroude et al., } \\
2018\end{array}$ \\
\hline \multicolumn{5}{|l|}{ Vitamin D } \\
\hline S. cerevisiae & DO was kept at $12 \%( \pm 1 \%)$ and pulse fed-batch was used. & MM medium & $1.16 \mathrm{~g} / \mathrm{L} \mathrm{VD} 2$ & Tan et al., 2003 \\
\hline R. erythropolis & $\begin{array}{l}\text { Insert the gene-expression cassette encoding Bacillus } \\
\text { megaterium glucose dehydrogenase-IV into the } \\
\text { chromosome of } R \text {. erythropolis. }\end{array}$ & MM medium & $573 \mathrm{mg} / \mathrm{L}$ VD 3 & $\begin{array}{l}\text { Yasutake et al., } \\
2013\end{array}$ \\
\hline \multicolumn{5}{|l|}{ Vitamin E } \\
\hline E. gracilis & $\begin{array}{l}\text { Add effective additives (homogentisate and L-tyrosine); } \\
\text { Optimize the concentration of ethanol and protein. }\end{array}$ & $\begin{array}{l}\text { KH medium; } \\
\text { Homogentisate; } \\
\text { L-tyrosine }\end{array}$ & $5.10 \mathrm{mg} / \mathrm{L}$ & $\begin{array}{l}\text { Tani and Tsumura, } \\
1989\end{array}$ \\
\hline E. gracilis & $\begin{array}{l}\text { Determination of the amount of } \alpha \text {-tocopherol produced } \\
\text { under photoautotrophically, heterotrophically or } \\
\text { photoheterotrophically. }\end{array}$ & $\begin{array}{l}\text { MM; } \\
\text { Methane }\end{array}$ & $8.60 \pm 0.22 \mathrm{mg} / \mathrm{L}$ & Grimm et al., 2015 \\
\hline Stichococcus bacillaris & Ballon bioreactor culture with MeJa as inducer. & $\begin{array}{l}\text { Methyl jasmonate (MeJa); } \\
\text { Algal culture }\end{array}$ & $0.60 \mathrm{mg} / \mathrm{g}(\mathrm{DW})$ & $\begin{array}{l}\text { Sivakumar et al., } \\
2014\end{array}$ \\
\hline Nannochloropsis oculata & $\begin{array}{l}\text { Optimize the carbon source of the medium }\left(\mathrm{NO}^{+}-\mathrm{N} \text { and }\right. \\
\left.\mathrm{NH}^{+}{ }_{-} \mathrm{N}\right) \text { and harvest time. }\end{array}$ & $\begin{array}{l}\text { F/2 medium; } \\
\text { Ammonium chloride }\end{array}$ & $\begin{array}{l}2.32 \pm 0.04 \mathrm{mg} / \mathrm{g} \\
(\mathrm{DW})\end{array}$ & Durmaz, 2007 \\
\hline S. cerevisiae & $\begin{array}{l}\text { Gene cloning from various photosynthetic organisms; } \\
\text { Codon optimization and protein truncation. }\end{array}$ & SD medium & 320 mg/L & Shen et al., 2020 \\
\hline \multicolumn{5}{|l|}{ Vitamin K (MK-4/MK-7) } \\
\hline B. subtilis natto & $\begin{array}{l}\text { Optimum media conditions and screening producing strain } \\
\text { (Different nutrients of the culture medium will affect the yield } \\
\text { of MK-7). }\end{array}$ & Glycerol & $62.32 \pm 0.34$ mg/L & $\begin{array}{l}\text { Berenjian et al., } \\
2011\end{array}$ \\
\hline B. subtilis natto & $\begin{array}{l}\text { Fermentation using soybean extract and screening highest } \\
\text { MK7 yielding strain from commercially available natto. }\end{array}$ & $\begin{array}{l}\text { Soy granules; } \\
\text { Amylase }\end{array}$ & $67.01 \pm 0.18 \mathrm{mg} / \mathrm{kg}$ & $\begin{array}{l}\text { Mahanama et al., } \\
2011\end{array}$ \\
\hline B. subtilis & $\begin{array}{l}\text { Deletion of } P A S-A \text {, kinB, spollA, spoOlIE, dhbB, and ptsG; } \\
\text { Overexpresion of menF, menB, menE, entC, ppsA, aroK, } \\
\text { ispA, hepS/T, kdpG, } d x r, d x s, \text { fni, menA. }\end{array}$ & LB Medium & 200 mg/L & Cui et al., 2019 \\
\hline B. subtilis & Overexpresion of BS20- qcrA-C and tat $A D-C D$. & LB Medium & $410 \mathrm{mg} / \mathrm{L}$ & Cui et al., 2020 \\
\hline
\end{tabular}

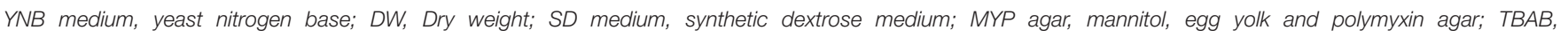
tetrabutylammonium bromide; CDW, cell dry weight.

natto, which is safe, natural and controllable, and occupies the mainstream position in the market. Compared with the chemically synthesized of trans-MK-7, it has a higher yield and fewer impurities.

\section{CONCLUSION}

The fermentative production of vitamins using bacteria, yeasts or microalgae has many advantages over traditional chemical synthesis methods. From the aspects of safety, biological activity, absorption rate, etc., vitamins manufactured by biological methods can be more suitable for both internal and external applications (Yuan et al., 2020). Although the fermentation of $\mathrm{VB}_{2}$ and $\mathrm{VB}_{12}$ has technologically matured and is being applied in industrial production, fermentation methods for the remaining B-group vitamins have yet to be developed or require significant yield improvement.
Vitamin C has a large market, and its production method is mainly based on single-bacteria fermentation, which eliminates the dependency of associated bacteria by replacing accompanying bacteria with associated active agents (Vandamme and Revuelta, 2016a). However, the current market situation indicates that vitamin $\mathrm{C}$ production has overcapacity, the downstream processing is complicated, and the market demand is concentrated in the field of medicine and food. For these reasons, the momentum of price increase will remain slow in the future. Vitamin $\mathrm{C}$ fermentation technology can explore the mechanism of a variety of accompanying bacteria, establish their anabolism database, or use isotope technology to label and trace the individual metabolites. It is also possible to design heterologous assembly modules for 2-KGA synthesis, and study adaptation mechanisms in microbial chassis cells, so as to achieve higher productivity (Liu et al., 2011).

The current biosynthesis product of vitamin A is mainly focused on $\beta$-carotene. The biosynthesis of $\beta$-carotene 
has successfully established a large-scale production process through classical and reasonable microbial metabolic engineering. However, due to the high barriers of intermediate industry and the complex process of synthesis and metabolism, the future research will face more difficult challenges. At present, the industrial production of vitamin $\mathrm{D}$ is mainly through the chemical synthesis of active $25-\mathrm{OH}-\mathrm{VD}_{3}$ and $1 \alpha, 25$-dihydroxyvitamin $\mathrm{D}_{3}$, but the biggest obstacle is the assured quality and security of supply for raw materials, which must be cholesterol with purity greater than 95\% (NF grade). Therefore, the key to solving the problem of raw materials is to develop more production bacteria, optimize their metabolic pathways and make them highly productive. With the continuous optimization and technological progress of vitamin $\mathrm{E}$ fermentation, the overall cost of the industry has fallen, which promoted the growth of the industry. Unfortunately, although studies have shown that photosynthetic microorganisms have considerable potential for the production of tocopherols, light-driven fermentation is costly, which makes commercialization difficult. However, due to the considerable potential E. gracilis and the conditions of the cultivation environment, the construction of a specifically designed photobioreactor may be a feasible research direction for the production of tocopherol. Moreover, the controllable temperature-sensitive control system may also be a key control technology for vitamin $\mathrm{E}$ production. Among vitamin $\mathrm{K}$ producing bacteria, B. subtilis natto seems to be the most promising candidate for MK production. Many researchers have optimized the design of fermentation modes, medium components, and culture conditions. They have also applied genetic engineering and other means to increase MK production (Szterk et al., 2018). However, to achieve higher industrial output, the technology needs to be further improved. Some studies have used biofilm reactors, which may become a promising new area for future research.

Recently, our research group used E. coli MG1655 (DE3) as chassis strains and achieved the de novo synthesis of vitamin $B_{12}$ via metabolic engineering and optimization of fermentation conditions. In addition, we have not only proved that E. coli is a microbial biosynthesis platform for the production of vitamin $B_{12}$, also provides an encouraging example of how the dozens of proteins in a complex biosynthetic pathway can be transferred between organisms to promote industrial production (Fang et al., 2018). In addition, our research group is also doing metabolism research on vitamin $B_{2}, B_{6}, B_{7}$, and vitamin $K$.

In general, the development of synthetic biotechnology provides new opportunities for the construction of vitamin cell factories. First, high-throughput screening of high-yield strains, the CRISPR/Cas9 genome editing technology, and automatic gene assembly technology provide important technical means

\section{REFERENCES}

Abbas, C. A., and Sibirny, A. A. (2011). Genetic control of biosynthesis and transport of riboflavin and flavin nucleotides and construction of robust for the mining and genetic modification of chassis cells (Chang et al., 2019; Zeng W. et al., 2020; Zhang and Showalter, 2020). Further, the output of vitamin products in different dimensions will be increased by transforming the complex and multi-enzyme pathways required for the production of vitamins, establishing microbial flora with controllable functions and stability, and application of some advanced engineering technology, such as the cold-shock-triggered temperature control system, dynamic control of gene expression systems, different types of biosensors, cell-free systems and computer-aided design, etc. (Koo et al., 2020; Marucci et al., 2020; Sachsenhauser et al., 2020; Shen et al., 2020; Glasscock et al., 2021). Additionally, the modular and orthogonal strategies are increasingly supporting the construction of vitamin cell factories (Liu et al., 2015). The mining and design of biological components, the assembly and integration of elements and modules, and the optimization and adaptation of the fermentation system are also important for efficient production of vitamins (Santos-Merino et al., 2019). However, there will be many challenges in the field of synthetic biotechnology in the future, including the compatibility between flexible biological systems and rigid engineering systems, or the universality of biological system reconstruction. It will be necessary and important to advance the existing technology, combine it with new strategies, and conduct interdisciplinary research to establish novel microbial cell factories for the industrial fermentation of most vitamins. All in all, we firmly believe that the industrialization of the fermentation production of vitamins is expected to become a broader, safer and more sustainable manufacturing with the continuous advancement of synthetic biotechnology and metabolic engineering.

\section{AUTHOR CONTRIBUTIONS}

YW and LL: manuscript planning, writing, and revision. ZJ and DZ: manuscript revision and writing. All authors contributed to the article and approved the submitted version.

\section{FUNDING}

This study was funded by the National Key R\&D Program of China (no. 2019YFA0905300), the National Natural Science Foundation of China under grants nos. 31670604 and 31970324, the Natural Science Foundation of Liaoning Province of China under grant no. 2019020758, the Science and Technology Project of Liaoning Education Department under grant no. 819001110761, and the Tianjin Synthetic Biotechnology Innovation Capacity Improvement Project (no. TSBICIP-CXRC004).

biotechnological producers. Microbiol. Mol. Biol. Rev. 75, 321-360. doi: 10. 1128/MMBR.00030-10

Acevedo-Rocha, C. G., Gronenberg, L. S., Mack, M., Commichau, F. M., and Genee, H. J. (2019). Microbial cell factories for the sustainable manufacturing 
of B vitamins. Curr. Opin. Biotechnol 56, 18-29. doi: 10.1016/j.copbio.2018. 07.006

Andreieva, Y., Petrovska, Y., Lyzak, O., Liu, W., and Sibirny, A. (2020). Role of the regulatory genes SEF1, VMA1 and SFU1 in riboflavin synthesis in the flavinogenic yeast Candida famata (Candida flareri). Yeast 37, 497-504. doi: 10.1002/yea.3503

Balasubramaniam, S., Christodoulou, J., and Rahman, S. (2019). Disorders of riboflavin metabolism. J. Inherited Metab. Dis. 42, 608-619.

Begley, T. P., Downs, D. M., Ealick, S. E., Mclafferty, F. W., Loon, A. P. G. M. V., Taylor, S., et al. (1999). Thiamin biosynthesis in prokaryotes. Arch. Microbiol. 171, 293-300. doi: 10.1007/s002030050713

Belenky, P., Stebbins, R., Bogan, K. L., Evans, C. R., and Brenner, C. (2011). Nrt1 and Tnal-independent export of NAD+ precursor vitamins promotes NAD+ homeostasis and allows engineering of vitamin production. PLoS One 6:e19710. doi: 10.1371/journal.pone.0019710

Berdanier, C. D., and Adkins, T. K. (2019). Water-soluble vitamins. Adv. Nutr. Micronutr.

Berenjian, A., Mahanama, R., Talbot, A., Biffin, R., Regtop, H., Valtchev, P., et al. (2011). Efficient media for high menaquinone-7 production: response surface methodology approach. N. Biotechnol. 28, 665-672. doi: 10.1016/j.nbt.2011.07. 007

Blake, C. J., and Konings, E. J. M. (2019). Committee on food nutrition: fat-soluble vitamins: water-soluble Vitamins. J. AOAC Int. 88, 325-330. doi: 10.1093/jaoac/ 88.1.325

Blanche, F., Cameron, B., Crouzet, J., Debussche, L., and Battersby, A. R. (1995a). Vitamin B12: how the problem of its biosynthesis was solved. Angewandte Chemie Int. Edition 34, 383-411. doi: 10.1002/chin.199527327

Blanche, F., Cameron, B., Crouzet, J., Debussche, L., and Battersby, A. R. (1995b). Vitamin B12: wie das problem seiner biosynthese gelöst wurde. Angewandte Chemie 107, 421-452. doi: 10.1002/ange.19951070404

Blanche, F., Cameron, B., Crouzet, J., Debussche, L., Levy-Schil, S., and Thibaut, D. (1992). Polypeptides involved in the biosynthesis of cobalamines and/or cobamides, dna sequences coding for these polypeptides, and their preparation and use. WO 1991011518:A1.

Burgess, C., O'Connell-Motherway, M., Sybesma, W., Hugenholtz, J., and van Sinderen, D. (2004). Riboflavin production in Lactococcus lactis: potential for in situ production of vitamin-enriched foods. Appl. Environ. Microbiol. 70, 5769-5777. doi: 10.1128/AEM.70.10.5769-5777.2004

Cai, Y., Xia, M., Dong, H., Qian, Y., Zhang, T., Zhu, B., et al. (2018). Engineering a vitamin B12 high-throughput screening system by riboswitch sensor in Sinorhizobium meliloti. BMC Biotechnol. 18:27. doi: 10.1186/s12896-018-04412

Capone, K., and Sentongo, T. (2019). The ABCs of nutrient deficiencies and toxicities. Pediatr. Ann. 48, e434-e440. doi: 10.3928/19382359-20191015-01

Cardinale, S., Tueros, F. G., and Sommer, M. O. A. (2017). Genetic-metabolic coupling for targeted metabolic engineering. Cell Rep. 20, 1029-1037. doi: 10. 1016/j.celrep.2017.07.015

Cea, P. A., Araya, G., Vallejos, G., Recabarren, R., and Castro-Fernandez, V. (2020). Characterization of hydroxymethylpyrimidine phosphate kinase from mesophilic and thermophilic bacteria and structural insights into their differential thermal stability. Arch. Biochem. Biophys. 688:108389. doi: 10.1016/ j.abb.2020.108389

Chand, T., and Savitri, B. (2016). Vitamin B3, Niacin. New York, NY: John Wiley \& Sons, Ltd.

Chang, H., Wang, C., Wang, P., Zhou, J., and Li, B. (2019). DNA assembly technologies: a review. Sheng Wu Gong Cheng Xue Bao 35, 2215-2226. doi: 10.13345/j.cjb.190273

Chauhan, N., and Poddar, R. (2019). In silico pharmacophore modeling and simulation studies for searching potent antileishmanials targeted against Leishmania donovani nicotinamidase. Comp. Biol. Chem. 83:107150. doi: 10. 1016/j.compbiolchem.2019.107150

Chen, J., Duan, P. L., Chen, L. H., Qiu, R. X., Cai, L. G., Hong, Z. L., et al. (2016). Bacillus Subtilis Natto and Method for Producting Protein MK-7. CN 104262129B. Beijing: China National Intellectual Property Administration.

Commichau, F. M., Alzinger, A., Sande, R., Bretzel, W., Reuss, D. R., Dormeyer, M., et al. (2015). Engineering Bacillus subtilis for the conversion of the antimetabolite 4-hydroxy-l-threonine to pyridoxine. Metab. Eng. 29, 196-207. doi: 10.1016/j.ymben.2015.03.007
Cui, S., Lv, X., Wu, Y., Li, J., Du, G., Ledesma-Amaro, R., et al. (2019). Engineering a bifunctional Phr60-Rap60-Spo0A quorum-sensing molecular switch for dynamic fine-tuning of menaquinone-7 synthesis in Bacillus subtilis. ACS Synth. Biol. 8, 1826-1837. doi: 10.1021/acssynbio.9b00140

Cui, S., Xia, H., Chen, T., Gu, Y., Lv, X., Liu, Y., et al. (2020). Cell membrane and electron transfer engineering for improved synthesis of menaquinone-7 in Bacillus subtilis. iScience 23:100918. doi: 10.1016/j.isci.2020.100918

Dmytruk, K., Lyzak, O., Yatsyshyn, V., Kluz, M., Sibirny, V., Puchalski, C., et al. (2014). Construction and fed-batch cultivation of Candida famata with enhanced riboflavin production. J. Biotechnol. 172, 11-17. doi: 10.1016/j.jbiotec. 2013.12.005

Dmytruk, K. V., Yatsyshyn, V. Y., Sybirna, N. O., Fedorovych, D. V., and Sibirny, A. A. (2011). Metabolic engineering and classic selection of the yeast Candida famata (Candida flareri) for construction of strains with enhanced riboflavin production. Metab. Eng. 13, 82-88. doi: 10.1016/j.ymben.2010.10.005

Dorrestein, P. C., Zhai, H., Mclafferty, F. W., and Begley, T. P. (2004). The biosynthesis of the thiazole phosphate moiety of thiamin. Chem. Biol. 11, 1373-1381. doi: 10.1016/j.chembiol.2004.08.009

Downs, D. M. (1992). Evidence for a new, oxygen-regulated biosynthetic pathway for the pyrimidine moiety of thiamine in Salmonella typhimurium. J. Bacteriol. 174, 1515-1521. doi: 10.1128/jb.174.5.1515-1521.1992

Downs, D. M., and Petersen, L. (1994). apbA, a new genetic locus involved in thiamine biosynthesis in Salmonella typhimurium. J. Bacteriol. 176, 4858-4864. doi: $10.1007 / \mathrm{BF} 02182164$

Downs, D. M., and Roth, J. R. (1991). Synthesis of thiamine in Salmonella typhimurium independent of the purF function. J. Bacteriol. 173, 6597-6604. doi: 10.1128/jb.173.20.6597-6604.1991

Durmaz, Y. (2007). Vitamin E ( $\alpha$-tocopherol) production by the marine microalgae Nannochloropsis oculata (Eustigmatophyceae) in nitrogen limitation. Aquaculture 272, 717-722. doi: 10.1016/j.aquaculture.2007.07.213

Eliot, A. C., and Kirsch, J. F. (2004). Pyridoxal phosphate enzymes: mechanistic, structural, and evolutionary considerations. Annu. Rev. Biochem. 73, 383-415. doi: 10.1146/annurev.biochem.73.011303.074021

Fang, H., Kang, J., and Zhang, D. (2017). Microbial production of vitamin B12: a review and future perspectives. Microbial Cell Factories 16:15. doi: 10.1186/ s12934-017-0631-y

Fang, H., Li, D., Kang, J., Jiang, P., Sun, J., and Zhang, D. (2018). Metabolic engineering of Escherichia coli for de novo biosynthesis of vitamin B12. Nat. Commun. 9:4917. doi: 10.1038/s41467-018-07412-6

Fischer, M., and Bacher, A. (2005). Biosynthesis of flavocoenzymes. Nat. Prod. Rep. 22, 324-350. doi: 10.1039/b210142b

Glasscock, C. J., Biggs, B. W., Lazar, J. T., Arnold, J. H., Burdette, L. A., Valdes, A., et al. (2021). Dynamic control of gene expression with riboregulated switchable feedback promoters. ACS Synth Biol. doi: 10.1021/acssynbio.1c00015 Online ahead of print.

Grimm, P., Risse, J. M., Cholewa, D., Muller, J. M., Beshay, U., Friehs, K., et al. (2015). Applicability of Euglena gracilis for biorefineries demonstrated by the production of $\alpha$-tocopherol and paramylon followed by anaerobic digestion. J. Biotechnol. 215, 72-79. doi: 10.1016/j.jbiotec.2015.04.004

Henrik, D. (1973). CLIV. The antihaemorrhagic vitamin of the chick. Nutrition Rev. 31:121. doi: 10.1111/j.1753-4887.1973.tb05050.x

Hohmann, H. P., Dijl, J. M. V., Krishnappa, L., and Prágai, Z. (2016). Host Organisms: Bacillus subtilis. Hoboken, NJ: John Wiley \& Sons, Ltd.

Holvik, K., Fryland, L., Haugen, M., Henjum, S., and Parr, C. L. (2019). Assessment of dietary intake of vitamin $\mathrm{K}$ and maximum limits for vitamin $\mathrm{K}$ in food supplements. Eur. J. Nutrition Food Safety 9, 96-98. doi: 10.9734/ejnfs/2019/ v9i230044

Hoshino, T., Ichikawa, K., and Nagahashi, Y. (2007). Microorganism and Process for Preparing Vitamin B6. Washington, DC: U.S. Patent and Trademark Office. U.S. Patent No 20060127992 A1.

Hoshino, T., Ichikawa, K., and Tazoe, M. (2004). Recombinant Microorganism for the Production. Washington, DC: U.S. Patent and Trademark Office. U.S. Patent No EP 1543139 B1.

Huser, A. T., Chassagnole, C., Lindley, N. D., Merkamm, M., Guyonvarch, A., Elisakova, V., et al. (2005). Rational design of a Corynebacterium glutamicum pantothenate production strain and its characterization by metabolic flux analysis and genome-wide transcriptional profiling. Appl. Environ. Microbiol. 71, 3255-3268. doi: 10.1128/AEM.71.6.3255-3268.2005 
Hwang, S., Cordova, B., Abdo, M., Pfeiffer, F., and Maupin-Furlow, J. A. (2017). ThiN as a versatile domain of transcriptional repressors and catalytic enzymes of thiamine biosynthesis. J. Bacteriol. 199:JB.00810-16. doi: 10.1128/JB.0081016

Ifuku, O., Koga, N., Haze, S., Kishimoto, J., Arai, T., and Wachi, Y. (1995). Molecular analysis of growth inhibition caused by overexpression of the biotin operon in Escherichia coli. Biosci. Biotechnol. Biochem. 59, 184-189. doi: 10. 1271/bbb. 59.184

Jagerstad, M., and Jastrebova, J. (2013). Occurrence, stability, and determination of formyl folates in foods. J. Agric. Food Chem. 61, 9758-9768. doi: 10.1021/ jf4028427

Jurgenson, C. T., Begley, T. P., and Ealick, S. E. (2009). The structural and biochemical foundations of thiamin biosynthesis. Annu. Rev. Biochem. 78, 569-603. doi: 10.1146/annurev.biochem.78.072407.102340

Kaiser, S., Di, M. P., Murphy, M. E., and Sies, H. (1990). Physical and chemical scavenging of singlet molecular oxygen by tocopherols. Arch. Biochem. Biophys. 277, 101-108. doi: 10.1016/0003-9861(90)90556-E

Kawahori, K., Kondo, Y., Yuan, X., Kawasaki, Y., and Hashimoto, K. (2020). Ascorbic acid during the suckling period is required for proper DNA demethylation in the liver. Sci. Rep. 10:21228. doi: 10.1038/s41598-02077962-7

Kawata, A., Murakami, Y., Suzuki, S., and Fujisawa, S. (2018). Anti-inflammatory activity of $\beta$-carotene, lycopene and tri-n-butylborane, a scavenger of reactive oxygen species. In Vivo 32, 255-264. doi: 10.21873/invivo.11232

Kim, S. T., Huh, W. K., Kim, J. Y., Hwang, S. W., and Kang, S. O. (1996). DArabinose dehydrogenase and biosynthesis of erythroascorbic acid in Candida albicans. Biochim. Biophys. Acta 1297, 1-8. doi: 10.1016/0167-4838(96)00077-5

Kim, S. T., Huh, W. K., Lee, B. H., and Kang, S. O. (1998). D-arabinose dehydrogenase and its gene from Saccharomyces cerevisiae. Biochim. Biophys. Acta 1429, 29-39. doi: 10.1016/S0167-4838(98)00217-9

Kitago, M., Kase, Y., Iwata, Y., Suwa, Y., Tsuchiya, H., Hanata, N., et al. (2020). Deteriorating anemia in an 86-year-old man was improved by prednisolone. Geriatr. Gerontol. Int. 20, 1091-1092. doi: 10.1111/ggi.14024

Koo, J., Yang, J., and Park, H. (2020). Cell-free systems: recent advances and future outlook. Biotechnol. Bioprocess Eng. 25, 955-961. doi: 10.1007/s12257020-0013-x

Larroude, M., Celinska, E., Back, A., Thomas, S., Nicaud, J. M., and Ledesma-Amaro, R. (2018). A synthetic biology approach to transform Yarrowia lipolytica into a competitive biotechnological producer of $\beta$-carotene. Biotechnol. Bioeng. 115, 464-472. doi: 10.1002/bit.26473

Leonardi, R., and Jackowski, S. (2007). Biosynthesis of pantothenic acid and coenzyme a. EcoSal Plus 2:10.1128/ecosallus.3.6.3.4. doi: 10.1128/ecosalplus.3. 6.3.4

Li, K. T., Liu, D. H., Chu, J., Wang, Y. H., Zhuang, Y. P., and Zhang, S. L. (2008). An effective and simplified $\mathrm{pH}$-stat control strategy for the industrial fermentation of vitamin $\mathrm{B}(12)$ by Pseudomonas denitrificans. Bioprocess Biosyst. Eng. 31, 605-610. doi: 10.1007/s00449-008-0209-5

Lin, S., and Cronan, J. E. (2011). Closing in on complete pathways of biotin biosynthesis. Mol. Biosyst. 7, 1811-1821. doi: 10.1039/c1mb05022b

Liu, L., Xu, W., Jia, H., and Wu, J. (2011). A novel and effective multi-constrained QoS routing scheme in WMNs. Front. Electrical Electronic Eng. China 6:507514. doi: 10.1007/s11460-011-0118-2

Liu, S., Dicker, K. T., and Jia, X. (2015). Modular and orthogonal synthesis of hybrid polymers and networks. Chem. Commun. (Camb) 51, 5218-5237. doi: $10.1039 / \mathrm{c} 4 \mathrm{cc} 09568 \mathrm{e}$

Lucock, M. (2000). Folic acid: nutritional biochemistry, molecular biology, and role in disease processes. Mol. Genet. Metab. 71, 121-138. doi: 10.1006/mgme.2000. 3027

Ma, Q., Bi, Y. H., Wang, E. X., Zhai, B. B., Dong, X. T., Qiao, B., et al. (2019). Integrated proteomic and metabolomic analysis of a reconstructed threespecies microbial consortium for one-step fermentation of 2-keto-L-gulonic acid, the precursor of vitamin C. J. Ind. Microbiol. Biotechnol. 46, 21-31. doi: 10.1007/s10295-018-2096-3

Mahanama, R., Berenjian, A., Valtchev, P., Talbot, A., Biffin, R., Regtop, H., et al. (2011). Enhanced production of menaquinone 7 via solid substrate fermentation from Bacillus subtilis. Int. J. Food Eng. 7, 1-2. doi: 10.2202/15563758.2314
Marucci, L., Barberis, M., Karr, J., Ray, O., Race, P. R., de Souza Andrade, M., et al. (2020). Computer-aided whole-cell design: taking a holistic approach by integrating synthetic with systems biology. Front. Bioeng. Biotechnol. 8:942. doi: $10.3389 /$ fbioe. 2020.00942

Moriguchi, S., and Muraga, M. (2000). Vitamin E and immunity. Vitamins Hormones-advances Res. Appl. 59, 305-336.

Morishita, T., Tamura, N., Makino, T., and Kudo, S. (1999). Production of menaquinones by lactic acid bacteria. J. Dairy Sci. 82, 0-1903. doi: 10.3168/jds. S0022-0302(99)75424-X

Muñoz, P., and Munné-Bosch, S. (2019). Vitamin E in plants: biosynthesis, transport, and function. Trends Plant Sci. 24, 1040-1051. doi: 10.1016/j.tplants. 2019.08.006

Myszczyszyn, A., Krajewski, R., Ostapów, M., and Hirnle, L. (2019). Folic acid role in the body, recommendations and clinical significance. Pielegniarstwo XXI wieku / Nursing in the 21st Century 18, 50-59. doi: 10.2478/pielxxiw-2019-0007

Nie, G., Yang, X., Liu, H., Wang, L., and Gong, G. (2013). N+ ion beam implantation of tannase-producing Aspergillus niger and optimization of its process parameters under submerged fermentation. Annals Microbiol. 63, 279287. doi: 10.1007/s13213-012-0471-2

Osman, D., Cooke, A., Young, T. R., Deery, E., and Warren, M. J. (2021). The requirement for cobalt in vitamin B12: a paradigm for protein metalation. Biochimica et Biophysica Acta (BBA) - Mol. Cell Res. 1868:118896. doi: 10.1016/ j.bbamcr.2020.118896

Paciolla, C., Fortunato, S., Dipierro, N., Paradiso, A., and Pinto, M. C. D. (2019). Vitamin C in plants: from functions to biofortification. Antioxidants 8:519. doi: $10.3390 /$ antiox8110519

Palmer, L. D., and Downs, D. M. (2013). The thiamine biosynthetic enzyme ThiC catalyzes multiple turnovers and is inhibited by S-adenosylmethionine (AdoMet) metabolites. J. Biol. Chem. 288, 30693-30699. doi: 10.1074/jbc.M113. 500280

Papoutsis, K., Grasso, S., Menon, A., Brunton, N. P., Lyng, J. G., Jacquier, J.-C., et al. (2020). Recovery of ergosterol and vitamin D2 from mushroom waste-potential valorization by food and pharmaceutical industries. Trends Food Sci. Technol. 99, 351-366. doi: 10.1016/j.tifs.2020.03.005

Rao, Y. M., and Sureshkumar, G. K. (2000). Direct biosynthesis of ascorbic acid from glucose by Xanthomonas campestris through induced free-radicals. Biotechnol. Lett. 22, 407-411. doi: 10.1023/B:DOBS.0000033277.54135.71

Sachsenhauser, V., Deng, X., Kim, H. H., Jankovic, M., and Bardwell, J. C. A. (2020). Yeast tripartite biosensors sensitive to protein stability and aggregation propensity. ACS Chem. Biol. 15, 1078-1088. doi: 10.1021/acschembio.0c00083

Sahm, H., and Eggeling, L. (1999). D-Pantothenate synthesis in Corynebacterium glutamicum and use of panBC and genes encoding L-valine synthesis for D-Pantothenate overproduction. Appl. Environ. Microbiol. 65, 1973-1979. doi: 10.1016/S0027-5107(99)00041-X

Sano, M., Ernesto, C., Thomas, R. G., Klauber, M. R., Schafer, K., Grundman, M., et al. (1997). A controlled trial of selegiline, alpha-tocopherol, or both as treatment for Alzheimer's disease. New England J. Med. 336, 1216-1222. doi: 10.1056/nejm199704243361704

Santos-Merino, M., Singh, A., and Ducat, D. (2019). New applications of synthetic biology tools for cyanobacterial metabolic engineering. Front. Bioeng. Biotechnol. 7:33. doi: 10.3389/fbioe.2019.00033

Sato, T., Yamada, Y., Ohtani, Y., Mitsui, N., Murasawa, H., and Araki, S. (2001) Efficient production of menaquinone (vitamin K2) by a menadione-resistant mutant of Bacillus subtilis. J. Ind. Microbiol. Biotechnol. 26, 115-120. doi: 10. 1038/sj/jim/7000089

Sauer, M., Branduardi, P., Valli, M., and Porro, D. (2004). Production of L-ascorbic acid by metabolically engineered Saccharomyces cerevisiae and Zygosaccharomyces bailii. Appl. Environ. Microbiol. 70, 6086-6091. doi: 10. 1128/AEM.70.10.6086-6091.2004

Schwalfenberg, G. K. (2017). Vitamins K1 and K2: the emerging group of vitamins required for human health. J. Nutr. Metab. 2017:6254836. doi: 10.1155/2017/ 6254836

Schwechheimer, S. K., Park, E. Y., Revuelta, J. L., Becker, J., and Wittmann, C. (2016). Biotechnology of riboflavin. Appl. Microbiol. Biotechnol. 100, $2107-$ 2119. doi: $10.1007 / \mathrm{s} 00253-015-7256-\mathrm{z}$

Schwarzhans, J.-P., Cholewa, D., Grimm, P., Beshay, U., Risse, J.-M., Friehs, K., et al. (2015). Dependency of the fatty acid composition of Euglena gracilis 
on growth phase and culture conditions. J. Appl. Phycol. 27, 1389-1399. doi: 10.1007/s10811-014-0458-4

Schyns, G., Potot, S., Geng, Y., Barbosa, T. M., Henriques, A., and Perkins, J. B. (2005). Isolation and characterization of new thiamine-deregulated mutants of Bacillus subtilis. J. Bacteriol. 187, 8127-8136. doi: 10.1128/JB.187.23.8127-8136. 2005

Selvam, S., Ramaian Santhaseela, A., Ganesan, D., Rajasekaran, S., and Jayavelu, T. (2019). Autophagy inhibition by biotin elicits endoplasmic reticulum stress to differentially regulate adipocyte lipid and protein synthesis. Cell Stress Chaperones 24, 343-350. doi: 10.1007/s12192-018-00967-9

Serrano-Amatriain, C., Ledesma-Amaro, R., Lopez-Nicolas, R., Ros, G., Jimenez, A., and Revuelta, J. L. (2016). Folic acid production by engineered Ashbya gossypii. Metab. Eng. 38, 473-482. doi: 10.1016/j.ymben.2016.10.011

Sharma, V., Meganathan, R., and Hudspeth, M. E. (1993). Menaquinone (vitamin $\mathrm{K} 2$ ) biosynthesis: cloning, nucleotide sequence, and expression of the menC gene from Escherichia coli. J. Bacteriol. 175, 4917-4921. doi: 10.1128/jb.175.15. 4917-4921.1993

Shen, B., Zhou, P., Jiao, X., Yao, Z., Ye, L., and Yu, H. (2020). Fermentative production of Vitamin E tocotrienols in Saccharomyces cerevisiae under coldshock-triggered temperature control. Nat. Commun. 11:5155. doi: 10.1038/ s41467-020-18958-9

Shi, Z., Zhen, S., Wittert, G. A., Yuan, B., Zuo, H., and Taylor, A. W. (2014). Inadequate riboflavin intake and anemia risk in a Chinese population: fve-year follow up of the Jiangsu Nutrition Study. PLoS One 9:e88862. doi: 10.1371/ journal.pone.0088862

Sivakumar, G., Jeong, K., and Lay, J. O. Jr. (2014). Biomass and RRR- $\alpha$-tocopherol production in Stichococcus bacillaris strain siva2011 in a balloon bioreactor. Microb. Cell Fact. 13:79. doi: 10.1186/1475-2859-13-79

Song, J., Liu, H., Wang, L., Dai, J., and Zheng, Z. (2014). Enhanced production of vitamin $\mathrm{K} 2$ from Bacillus subtilis (natto) by mutation and optimization of the fermentation medium. Braz. Arch. Biol. Technol. 57, 606-612. doi: 10.1590/ S1516-8913201402126

Streit, W. R., and Entcheva, P. (2003). Biotin in microbes, the genes involved in its biosynthesis, its biochemical role and perspectives for biotechnological production. Appl. Microbiol. Biotechnol. 61, 21-31. doi: 10.1007/s00253-0021186-2

Sugimoto, T., Kanamasa, S., Kato, T., and Park, E. Y. (2009). Importance of malate synthase in the glyoxylate cycle of Ashbya gossypii for the efficient production of riboflavin. Appl. Microbiol. Biotechnol. 83, 529-539. doi: 10.1007/s00253-0091972-1

Sugisawa, T., Miyazaki, T., and Hoshino, T. (2005). Microbial production of L-Ascorbic acid from D-Sorbitol, L-Sorbose, L-Gulose, and L-Sorbosone by Ketogulonicigenium vulgare DSM 4025. Biosci. Biotechnol. Biochem. 69, 659662. doi: $10.1271 /$ bbb.69.659

Suter, P. M. (2020). The B-vitamins. Essential Toxic Trace Elements Vitamins Hum. Health 2020, 217-239 doi: 10.1016/B978-0-12-805378-2.00017-6

Sych, J. M., Lacroix, C., and Stevens, M. J. A. (2016). Vitamin B12 - Physiology, Production and Application. Weinheim: Wiley-VCH Verlag $\mathrm{GmbH} \& \mathrm{Co}$. KGaA.

Szterk, A., Zmyslowski, A., and Bus, K. (2018). Identification of cis/trans isomers of menaquinone-7 in food as exemplified by dietary supplements. Food Chem. 243, 403-409. doi: 10.1016/j.foodchem.2017.10.001

Taguchi, H., Shibata, T., Duangmanee, C., and Tani, Y. (2014). Menaquinone4 production by a sulfonamide-resistant mutant of Flavobacterium sp. Agricultural Biol. Chem. 53, 3017-3023. doi: 10.1080/00021369.1989.10869800

Taketomi, H., Soda, K., and Katsui, G. (1983). Results of screening test in tocopherols in microbial realm. Vitamins 57, 133-138.

Tan, T., Zhang, M., and Gao, H. (2003). Ergosterol production by fed-batch fermentation of Saccharomyces cerevisiae. Enzyme Microbial Technol. 33, 366370. doi: 10.1016/s0141-0229(03)00132-7

Tanaka, T., Tateno, Y., and Gojobori, T. (2005). Evolution of vitamin B6 (pyridoxine) metabolism by gain and loss of genes. Mol. Biol. Evol. 22, 243-250. doi: $10.1093 / \mathrm{molbev} / \mathrm{msi011}$

Tani, Y., and Tsumura, H. (1989). Screening for tocopherol-producing microorganisms and $\alpha$-tocopherol production by Euglena gracilis $\mathrm{Z}$. Agricultural Biol. Chem. 53, 305-312. doi: 10.1271/bbb1961.53.305

Tannous, C., Booz, G. W., Altara, R., Muhieddine, D. H., and Zouein, F. A. (2020). Nicotinamide adenine dinucleotide: biosynthesis, consumption, and therapeutic role in cardiac diseases. Acta Physiol. 231:e13551. doi: 10.1111/apha. 13551

Timoshnikov, V. A., Kobzeva, T. V., Polyakov, N. E., and Kontoghiorghes, G. J. (2020). Redox interactions of vitamin C and iron: inhibition of the prooxidant activity by deferiprone. Int. J. Mol. Sci. 21:3967. doi: 10.3390/ijms 21113967

Tokui, M., Kubodera, T., Gomi, K., Yamashita, N., and Nishimura, A. (2011). Construction of a thiamine pyrophosphate high-producing strain of Aspergillus oryzae by overexpression of three genes involved in thiamine biosynthesis. J. Biosci. Bioeng. 111, 388-390. doi: 10.1016/j.jbiosc.2010.12.011

Van Arsdell, S. W., Perkins, J. B., Yocum, R. R., Luan, L., Howitt, C. L., Chatterjee, N. P., et al. (2005). Removing a bottleneck in the Bacillus subtilis biotin pathway: BioA utilizes lysine rather than S-adenosylmethionine as the amino donor in the KAPA-to-DAPA reaction. Biotechnol. Bioeng. 91, 75-83. doi: 10.1002/bit.20488

Vandamme, E. J., and Revuelta, J. L. (2016a). "Industrial fermentation of vitamin C," in Industrial Biotechnology of Vitamins, Biopigments, and Antioxidants, eds E. J. Vandamme and J. L. Revuelta (Weinheim: Wiley-VCH Verlag GmbH \& Co. KGaA), 161-192. doi: 10.1002/9783527681754.ch7

Vandamme, E. J., and Revuelta, J. L. (2016b). "Vitamins, biopigments, antioxidants and related compounds: a historical, physiological and (bio)technological perspective," in Industrial Biotechnology of Vitamins, Biopigments, and Antioxidants, eds E. J. Vandamme and J. L. Revuelta (Weinheim: Wiley-VCH Verlag GmbH \& Co. KGaA).

Wang, Z., Liu, Z., Cui, W., and Zhou, Z. (2017). Establishment of bioprocess for synthesis of nicotinamide by recombinant Escherichia coli expressing highmolecular-mass nitrile hydratase. Appl. Biochem. Biotechnol. 182, 1458-1466. doi: 10.1007/s12010-017-2410-y

Wise, L. A., Wesselink, A. K., Bethea, T. N., Brasky, T. M., Wegienka, G., Harmon, Q., et al. (2021). Intake of lycopene and other carotenoids and incidence of uterine leiomyomata: a prospective ultrasound study. J. Acad. Nutr. Diet. 121, 92-104. doi: 10.1016/j.jand.2020.08.013

$\mathrm{Wu}, \mathrm{W} .-\mathrm{J}$. (2011). Isolation and identification of Bacillus amyloliquefaciens BY01 with high productivity of menaquinone for Cheonggukjang production. J. Korean Soc. Appl. Biol. Chem. 54, 783-789. doi: 10.3839/jksabc.2011.118

Xia, W., Chen, W., Peng, W. F., and Li, K. T. (2015). Industrial vitamin B12 production by Pseudomonas denitrificans using maltose syrup and corn steep liquor as the cost-effective fermentation substrates. Bioprocess Biosyst. Eng. 38, 1065-1073. doi: 10.1007/s00449-014-1348-5

Yang, Y., Li, R., Hui, J., Li, L., and Zheng, X. (2021). $\beta$-Carotene attenuates LPSinduced rat intestinal inflammation via modulating autophagy and regulating the JAK2/STAT3 and JNK/p38 MAPK signaling pathways. J. Food Biochem. 45:e13544. doi: 10.1111/jfbc.13544

Yasutake, Y., Nishioka, T., Imoto, N., and Tamura, T. (2013). A single mutation at the ferredoxin binding site of $\mathrm{P} 450 \mathrm{Vdh}$ enables efficient biocatalytic production of 25-hydroxyvitamin D(3). Chembiochem 14, 2284-2291. doi: 10.1002/cbic. 201300386

Yoon, S. H., Lee, S. H., Das, A., Ryu, H. K., Jang, H. J., Kim, J. Y., et al. (2009). Combinatorial expression of bacterial whole mevalonate pathway for the production of $\beta$-carotene in E. coli. J. Biotechnol. 140, 218-226. doi: 10.1016/ j.jbiotec.2009.01.008

Yuan, P., Cui, S., Liu, Y., Li, J., and Liu, L. (2020). Metabolic engineering for the production of fat-soluble vitamins: advances and perspectives. Appl. Microbiol. Biotechnol. 104, 935-951. doi: 10.1007/s00253-019-10157-x

Zeng, W., Guo, L., Xu, S., Chen, J., and Zhou, J. (2020). High-throughput screening technology in industrial biotechnology. Trends Biotechnol. 38, 888-906. doi: 10.1016/j.tibtech.2020.01.001

Zeng, Z., Han, N., Liu, C., Buerte, B., Zhou, C., Chen, J., et al. (2020). Functional dissection of HGGT and HPT in barley vitamin E biosynthesis via CRISPR/Cas9-enabled genome editing. Annals Bot. 126, 929-942. doi: 10.1093/ aob/mcaal15

Zhang, Y., and Showalter, A. M. (2020). CRISPR/Cas9 genome editing technology: a valuable tool for understanding plant cell wall biosynthesis and function. Front. Plant Sci. 11:589517. doi: 10.3389/fpls.2020.589517

Zhao, J., Li, Q., Sun, T., Zhu, X., Xu, H., Tang, J., et al. (2013). Engineering central metabolic modules of Escherichia coli for improving $\beta$-carotene production. Metab. Eng. 17, 42-50. doi: 10.1016/j.ymben.2013.02.002

Zhou, J., Chen, J., Duan, L., Zhang, M., Guochun, Q. U., Feng, X. U., et al. (2019). Update on the mechanism of vitamin $\mathrm{K} 2(\mathrm{MK}-7)$ in preventing and treating 
osteoporosis. Chinese J. Osteoporosis. 25, 539-545 doi: 10.3969/j.issn.10067108.2019 .04 .023

Conflict of Interest: The authors declare that the research was conducted in the absence of any commercial or financial relationships that could be construed as a potential conflict of interest.
Copyright (๑) 2021 Wang, Liu, Jin and Zhang. This is an open-access article distributed under the terms of the Creative Commons Attribution License (CC BY). The use, distribution or reproduction in other forums is permitted, provided the original author(s) and the copyright owner(s) are credited and that the original publication in this journal is cited, in accordance with accepted academic practice. No use, distribution or reproduction is permitted which does not comply with these terms. 